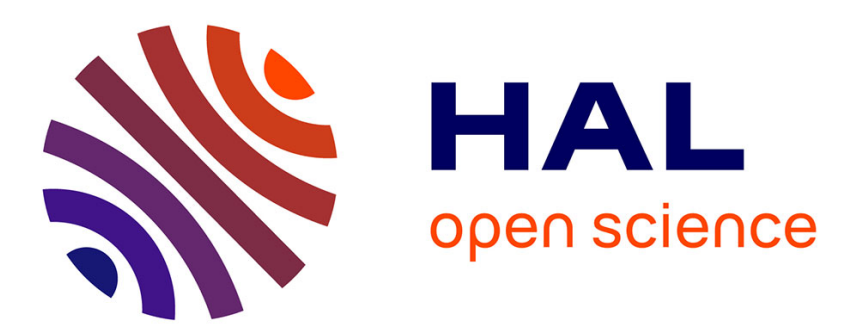

\title{
Design, synthesis and biological evaluation of potential antibacterial butyrolactones
}

\author{
A. Sweidan, M. Chollet-Krugler, P. van De Weghe, A. Chokr, S. Tomasi, M. \\ Bonnaure-Mallet, Latifa Bousarghin
}

\section{- To cite this version:}

A. Sweidan, M. Chollet-Krugler, P. van De Weghe, A. Chokr, S. Tomasi, et al.. Design, synthesis and biological evaluation of potential antibacterial butyrolactones. Bioorganic and Medicinal Chemistry, 2016, 24 (22), pp.5823-5833. 10.1016/j.bmc.2016.09.040 . hal-01398051

\section{HAL Id: hal-01398051}

\section{https://hal-univ-rennes1.archives-ouvertes.fr/hal-01398051}

Submitted on 5 Jan 2017

HAL is a multi-disciplinary open access archive for the deposit and dissemination of scientific research documents, whether they are published or not. The documents may come from teaching and research institutions in France or abroad, or from public or private research centers.
L'archive ouverte pluridisciplinaire HAL, est destinée au dépôt et à la diffusion de documents scientifiques de niveau recherche, publiés ou non, émanant des établissements d'enseignement et de recherche français ou étrangers, des laboratoires publics ou privés. 


\section{Accepted Manuscript}

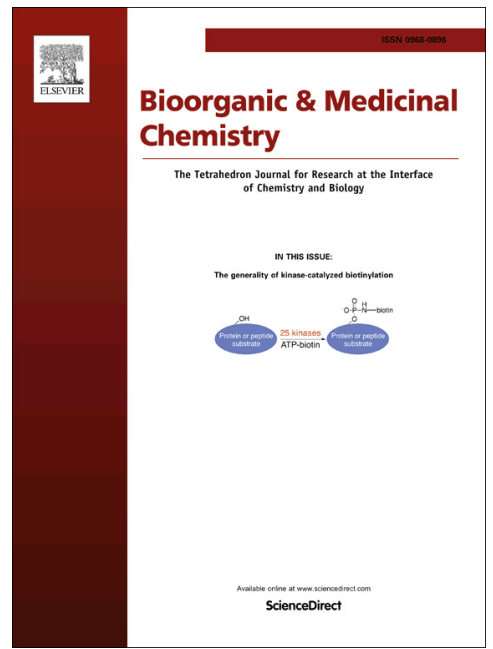

Design, Synthesis and Biological Evaluation of Potential Antibacterial Butyrolactones

Alaa Sweidan, Marylene Chollet-Krugler, Pierre van de Weghe, Ali Chokr, Sophie Tomasi, Martine Bonnaure-Mallet, Latifa Bousarghin

PII: S0968-0896(16)30734-9

DOI: http://dx.doi.org/10.1016/j.bmc.2016.09.040

Reference: BMC 13293

To appear in:

Bioorganic \& Medicinal Chemistry

Received Date:

22 June 2016

Revised Date: 14 September 2016

Accepted Date: 15 September 2016

Please cite this article as: Sweidan, A., Chollet-Krugler, M., Weghe, P.v.d., Chokr, A., Tomasi, S., Bonnaure-Mallet, M., Bousarghin, L., Design, Synthesis and Biological Evaluation of Potential Antibacterial Butyrolactones, Bioorganic \& Medicinal Chemistry (2016), doi: http://dx.doi.org/10.1016/j.bmc.2016.09.040

This is a PDF file of an unedited manuscript that has been accepted for publication. As a service to our customers we are providing this early version of the manuscript. The manuscript will undergo copyediting, typesetting, and review of the resulting proof before it is published in its final form. Please note that during the production process errors may be discovered which could affect the content, and all legal disclaimers that apply to the journal pertain. 


\section{Graphical Abstract}

\section{Design, synthesis and \\ biological evaluation \\ of potential \\ antibacterial \\ butyrolactones}

Alaa Sweidan, ${ }^{\text {a,c }}$ Marylene Chollet-Krugler, ${ }^{\mathrm{b}}$ Pierre van de Weghe, ${ }^{\mathrm{b}}$ Ali Chokr, ${ }^{\mathrm{c}}$ Sophie Tomasi, ${ }^{\mathrm{b}}$ Martine Bonnaure-Mallet, ${ }^{\mathrm{a}}$ Latifa Bousarghin ${ }^{* a}$

${ }^{a}$ Equipe Microbiologie Risques Infectieux, EA 1254, SFR Biosit, Université Bretagne

Loire, Université de Rennes 1, 2 Avenue du Professeur Léon Bernard, 35043 Rennes, France

${ }^{b}$ UMR CNRS 6226, Institut des Sciences Chimiques de Rennes, Equipe PNSCM, Université Bretagne Loire, Université de Rennes 1, 2 Avenue du Pr. Léon Bernard, F-35043 Rennes, France

c Laboratory of Microbiology, Department of Biology, Faculty of Sciences I, Lebanese University, Hadath Campus, Beirut, Lebanon

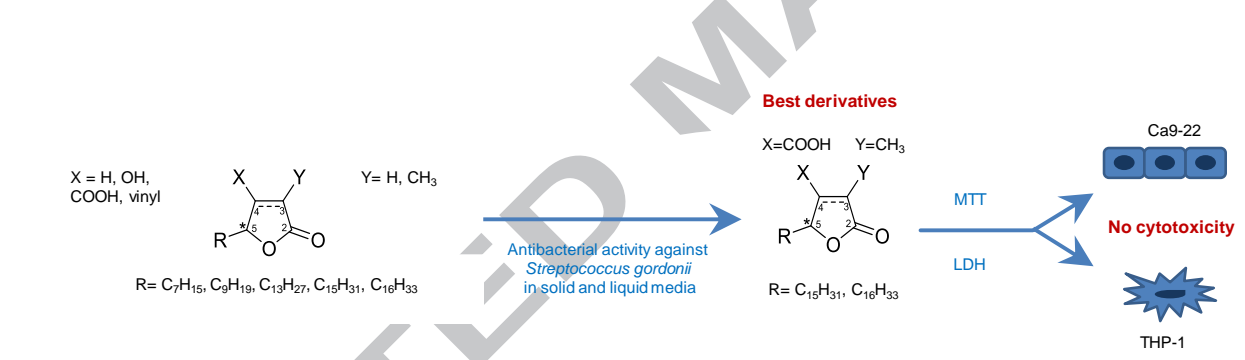




\title{
Bioorganic \& Medicinal Chemistry \\ journal homepage: www.elsevier.com
}

\section{Design, Synthesis and Biological Evaluation of Potential Antibacterial Butyrolactones}

\author{
Alaa Sweidan ${ }^{\mathrm{a}, \mathrm{c}}$, Marylene Chollet-Krugler ${ }^{\mathrm{b}}$, Pierre van de Weghe ${ }^{\mathrm{b}}$, Ali Chokr ${ }^{\mathrm{c}}$, Sophie Tomasi ${ }^{\mathrm{b}}$, Martine \\ Bonnaure-Mallet $^{\mathrm{a}}$, and Latifa Bousarghin ${ }^{\mathrm{a}^{*}}$ \\ ${ }^{a}$ Equipe Microbiologie Risques Infectieux, EA 1254, SFR Biosit, Université Bretagne Loire, Université de Rennes 1, 2 Avenue du Professeur Léon Bernard, \\ 35043 Rennes, France \\ ${ }^{b}$ UMR CNRS 6226, Institut des Sciences Chimiques de Rennes, Equipe PNSCM, Université Bretagne Loire, Université de Rennes 1, 2 Avenue du Pr. Léon \\ Bernard, F-35043 Rennes, France \\ ${ }^{c}$ Laboratory of Microbiology, Department of Biology, Faculty of Sciences I, Lebanese University, Hadath Campus, Beirut, Lebanon
}

\section{ARTICLE INFO}

Article history:

Received

Received in revised form

Accepted

Available online

Keywords:

Lichen

Butyrolactones

Streptococcus gordonii

Antibacterial

Cytotoxicity

\section{ABSTRACT}

Novel butyrolactone analogues were designed and synthesized based on the known lichen antibacterial compounds, lichesterinic acids (B-10 and B-11), by substituting different functional groups on the butyrolactone ring trying to enhance its activity. All synthesized butyrolactone analogues were evaluated for their in vitro antibacterial activity against Streptococcus gordonii. Among the derivatives, B-12 and B-13 had the lowest MIC of $9.38 \mu \mathrm{g} / \mathrm{mL}$ where they have shown to be stronger bactericidals, by 2-3 times, than the reference antibiotic, doxycycline. These two compounds were then checked for their cytotoxicity against human gingival epithelial cell lines, Ca9-22, and macrophages, THP-1, by MTT and LDH assays which confirmed their safety against the tested cell lines. A preliminary study of the structure-activity relationships unveiled that the functional groups at the $\mathrm{C}_{4}$ position had an important influence on the antibacterial activity. An optimum length of the alkyl chain at the $\mathrm{C}_{5}$ position registered the best antibacterial inhibitory activity however as its length increased the bactericidal effect increased as well. This efficiency was attained by a carboxyl group substitution at the $\mathrm{C}_{4}$ position indicating the important dual role contributed by these two substituents which might be involved in their mechanism of action.

2009 Elsevier Ltd. All rights reserved

\section{Introduction}

The usages of antibiotics on a large scale alongside their misapplication have lead to the emergence of resistant pathogenic bacteria. ${ }^{1}$ Both, the infection of these re-emergent strains which has increased the global mortality rate to be a growing concern and the global reduction in antibiotics production open a new era where other potent candidates should be found to fight against bacteria. ${ }^{2}$ Indeed, an infinite number of plant species have been tested against a huge number of bacterial strains in vitro. In addition, many phytochemicals found effective against a broad spectrum of microorganisms comprising fungi, yeast and bacteria were uncovered. ${ }^{3}$ Throughout the last 2 decades, plants are becoming a famous rich source of antimicrobial substances. ${ }^{4}$ Furthermore, many other promising drug sources still need to be explored. ${ }^{5}$ Lichens which are symbiotic organisms comprising a fungus and a photosynthetic alga and/or cyanobacterium constitutes a potential source of over 1000 distinct secondary metabolites. ${ }^{6}$ They comprise antitumor, antiviral and antimicrobial activities. $^{6-9}$ Sensitive as well as several multi-drug resistant bacterial strains were shown to be susceptible to these lichen compounds. ${ }^{6}$ Streptococcus gordonii (S. gordonii) is an eminent member of the viridans streptococci large category. Not only was this bacteria described as an agent of septic arthritis but also it can colonise damaged heart valves and represents the primary etiological agent of subacute bacterial endocarditis. ${ }^{10}$ In the oral cavity, S. gordonii adhere to the salivary pellicle which coats the teeth, proliferate and excrete an extracellular polysaccharide matrix protecting their developing microcolony on which secondary colonizers will adhere. ${ }^{11}$ The late colonizing strains such as Porphyromonas gingivalis bind the sites provided by $S$. gordonii and form a highly pathogenic complex microbial community. ${ }^{12,13}$ S. gordonii as a pioneer initial colonizer initiates the formation of dental plaques contributing in turn to the onset of dental caries and periodontal diseases as well as their progression. ${ }^{14,15}$ Inhibiting $S$. gordonii might block the successive steps leading to acute oral diseases and this may constitute prevention rather than a risky cure after biofilm formation.

To address this oral issue, we synthesized a natural butyrolactone, $L$-lichesterinic acid. Cavalito et al have extracted it from the lichen, Cetraria islandica, and shown to have an activity against Streptococcus hemolyticus and Staphylococcus aureus. ${ }^{16}$ Our goal in this study is to evaluate its antibacterial activity against $S$. gordonii in solid and liquid media under anaerobic conditions. Trying to enhance its activity, some derivatives were synthesized and tested (Fig. 1). Finally, the cytotoxic effect of the most active compounds was 
evaluated on two human cell lines, gingival epithelial cells, Ca9-22, and macrophages, THP-1. To the best of our knowledge, it is the first study to describe some of these synthetic derivatives, their antibacterial activity against $S$. gordonii and their cytotoxic effects.

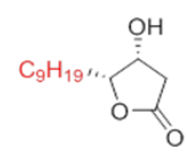

B-1

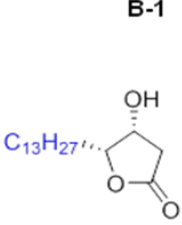

B-2

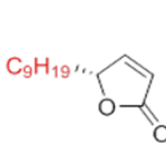

B-3<smiles>C=C[C@H]1CC(=O)O[C@@H]1[18CH]</smiles>

B-5<smiles>CC1=C(C(=O)O)[C@H]([13CH2])[C@@H](C(=O)O)OC1=O</smiles>

B-8

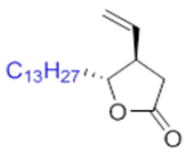

B-6<smiles>CCCCC[C@H]1OC(=O)C(C)=C(C(=O)O)[C@@H]1[14CH3]</smiles>

B-10

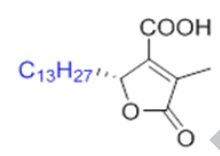<smiles>CC1=C(C(=O)O)[C@H]([18CH])OC1=O</smiles>

B-9<smiles>[B][B]</smiles><smiles>CC[C@H]1OC(=O)C(C)=C1C(=O)O</smiles>

B-7<smiles>CC1=C(C(=O)O)[C@H]([13CH2][13CH3])[C@@H](C(=O)O)OC1=O</smiles>

B-12<smiles>CCCCC[C@@H]1OC(=O)C(C)=C(C(=O)O)[C@@H]1[13CH2]</smiles>

B-13

Figure 1. Chemical structures of butyrolactones

\section{Results and Discussion}

\subsection{Chemistry}

Scheme 1 illustrates the synthesis of enantiopure (-)-lichesterinic acid B-10 and its derivatives. This straightforward asymmetric synthesis has already been described by Braukmüller and Brückner in 2006 for the preparation of paraconic acids. ${ }^{17}$ To the best of our knowledge, this strategy had been used only for the synthesis of naturally aliphatic $\alpha$-methylene butyrolactone (+)-methylenolactocin $\left(\mathrm{R}=\mathrm{C}_{5} \mathrm{H}_{11}\right)$ and (+)-protolichesterinic acid $\left(\mathrm{R}=\mathrm{C}_{13} \mathrm{H}_{27}\right)$ and their (-) enantiomers (Fig. 2). Based on a six steps method, one additional step is required to obtain a series of lichesterinic acid derivatives by isomerization of the double bond. Moreover, this lactone strategy has been extended to include different alkyl chain lengths $\mathrm{R}\left(\mathrm{C}_{7} \mathrm{H}_{15}, \mathrm{C}_{9} \mathrm{H}_{19}, \mathrm{C}_{15} \mathrm{H}_{31}\right.$, and $\left.\mathrm{C}_{16} \mathrm{H}_{33}\right)$. Briefly, it began with the preparation of hydroxyl lactones 1a-e where the enantiocontrol was imposed by the asymmetric dihydroxylation of trans-configured $\beta, \gamma$-unsaturated carboxylic ester with $\mathrm{AD}$ mix- $\alpha \AA$ or $\mathrm{AD}$ mix- $\beta 囚$. The resulting lactones were deshydrated giving butenolides 2a-e. For the two next steps we modified the approach according to Perepogu et al. ${ }^{18}$ A Gilman addition of a vinyl group was added trans-selectively to the $\mathrm{C}=\mathrm{C}$ bond giving vinyl lactones 3a-e, followed by an oxidation of the double bond allowing access to $\mathrm{HO}_{2} \mathrm{C}$-substituted lactones $\mathbf{4 a - e}$. $\alpha$-Activation by Stiles' reagent, followed by amino-methylation in situ fragmentation provided the $\alpha$-methylene butyrolactones $\mathbf{5 a - e}$. Then, the target enantiopure lichesterinic acid derivatives 6a-e were obtained by isomerization of the double bond using $\mathrm{NEt}_{3}$ in $\mathrm{DMF}_{\text {. }}$ This synthesis is achieved in seven steps and around $10 \%$ overall yield with good enantioselective excess determined by chiral HPLC.<smiles>C=C1C(=O)O[C@@H](Cc2ccccc2)C1C(=O)O</smiles>

(+)-methylenolactocin<smiles>C=C1C(=O)O[C@@H]([12CH2])[C@@H]1C(=O)O</smiles>

(+)-protolichesterinic

Figure 2. Chemical structures of two aliphatic $\alpha$-methylene butyrolactones 


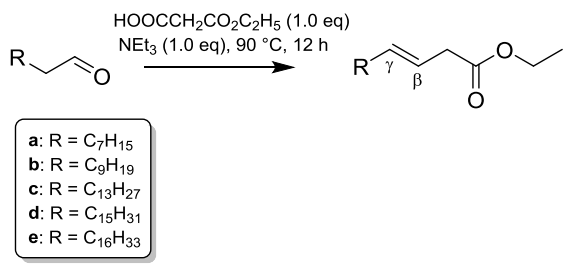

$\mathrm{AD}$ mix $-\beta \otimes$ or $\mathrm{AD}$ mix $\alpha \Theta$
$\mathrm{MeSO}_{2} \mathrm{NH}_{2}(1.0 \mathrm{eq})$

$\underset{\text { (overall } 63 \% \text { in } 2 \text { steps) }}{\longrightarrow}$

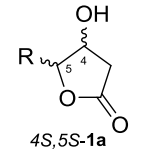

$4 S, 5 S-1 \mathbf{a}$

$4 S, 5 S-1 \mathbf{b}$

$4 R, 5 R-1 \mathbf{b}=\mathbf{B}-1$

$4 S, 5 S-1 \mathrm{c}$

$4 R, 5 R-1 \mathrm{c}=\mathrm{B}-2$

$4 S, 5 S-1 \mathrm{~d}$

$4 S, 5 S-1 \mathrm{e}$

(80-90\%) $\quad \mathrm{MsCl}(1.1 \mathrm{eq})$

$\mathrm{NEt}_{3}(2.1 \mathrm{eq})$

$\mathrm{CH}_{2} \mathrm{Cl}_{2}, 0^{\circ} \mathrm{C}, 15 \mathrm{~min}$
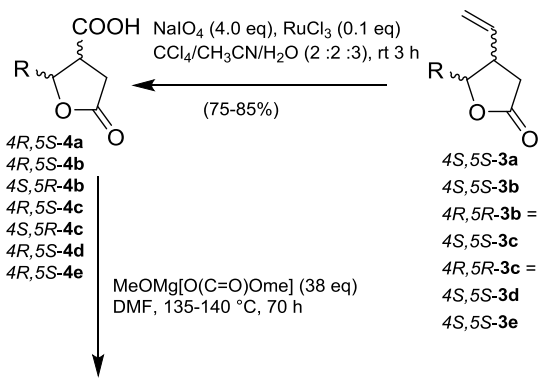

a- Cul (5 eq),THF, $-78^{\circ} \mathrm{C}$, MeLi ( 5 eq), $15 \mathrm{~min}$ b- vinylmagnesium bromide (5 eq), $15 \mathrm{~min}$ c- butyrolactone, $2 \mathrm{~h}, \mathrm{rt}$
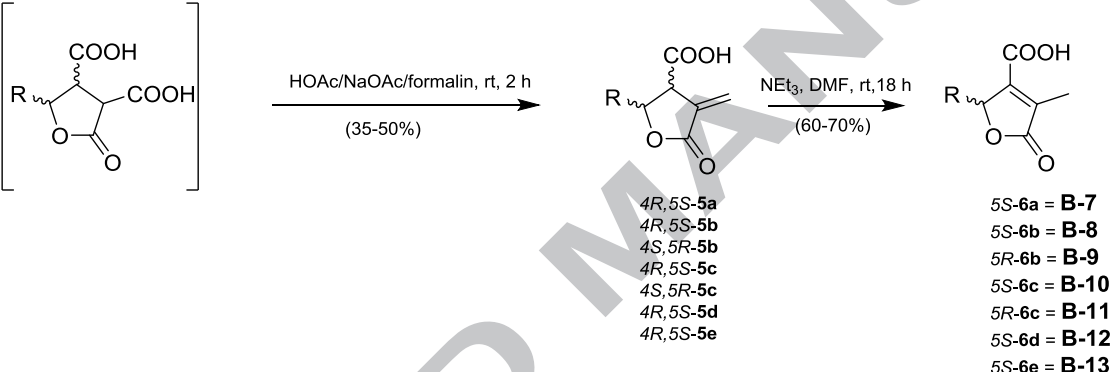

Scheme 1. Enantioselective synthesis route of butyrolactones

\subsection{Biological activity}

\subsubsection{Antibacterial activity}

\subsubsection{Agar dilution}

Seven out of the thirteen butyrolactones screened (Fig. 1) showed an activity with the concentrations tested against $S$. gordonii under anaerobic conditions (Table 1). Compounds B-2, B-4, B-5, B-6, B-7, and B-13 didn't exhibit any activity. The least active compounds were B-1 and B-3 showing the highest Minimal Inhibitory Concentration (MIC) of $300 \mu \mathrm{g} / \mathrm{mL}$. Then, the MIC decreased to be 200 $\mu \mathrm{g} / \mathrm{mL}$ for B-12 and continued decreasing to pass by $150 \mu \mathrm{g} / \mathrm{mL}$ for B-8 and B-9 and reaches the lowest value with B-10 and B-11 registering $90 \mu \mathrm{g} / \mathrm{mL}$ (Fig. 3A, Table 1). Alongside, doxycycline displayed an MIC of $0.41 \mu \mathrm{g} / \mathrm{mL}$ which was fixed and used always as a positive control (Fig. 3B, Table 1). In addition, the mixture of the solvents (DMSO + methanol) used to dissolute our compounds was found inactive at the highest concentration tested. These results were taken into the liquid medium to confirm and compare. 


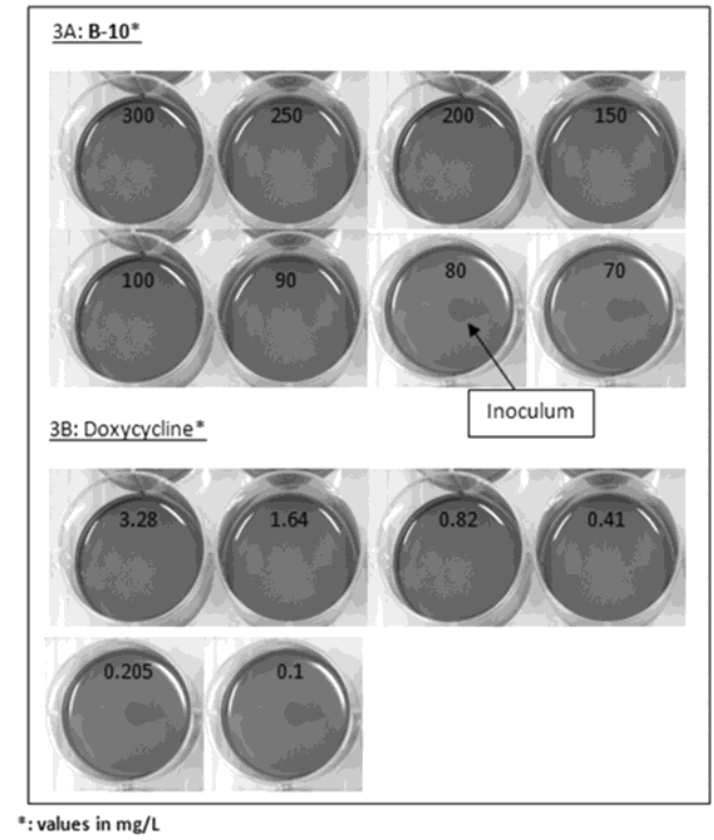

Figure 3. Effect of butyrolactones on S. gordonii in agar dilution

\subsubsection{Broth microdilution}

Compared to the solid medium, all butyrolactones were found active except B-7. At this step, B-2, B-4, B-5 and B-6 joined the antibacterial panel (Table 2).

According to the efficiency of the compounds, they can be distributed into 3 groups. The least efficient were $\mathbf{B}-\mathbf{1}, \mathbf{B}-\mathbf{3}, \mathbf{B}-\mathbf{7}, \mathbf{B}-\mathbf{8}$, and B-9. The most effective were B-10, B-11, B-12, and B-13.

The highest inhibitory activity was for B-10 and B-11 which registered the same results with MIC $=4.69 \mu \mathrm{g} / \mathrm{mL}$ and Minimal Bactericidal Concentration $(\mathrm{MBC})=18.75 \mu \mathrm{g} / \mathrm{mL}$. While MIC increased to be $9.38 \mu \mathrm{g} / \mathrm{mL}$ for B-12, its MBC remained at the same value. B-13 showed the same MIC as B-12 and it was also its MBC exhibiting the strongest killing effect.

Doxycycline activity decreased here to have $\mathrm{MIC}=0.51 \mu \mathrm{g} / \mathrm{mL}$ and $\mathrm{MBC}=32.8 \mu \mathrm{g} / \mathrm{mL}$ which were fixed and used always as positive control. If we compare butyrolactones to doxycycline antibiotic, we can notice that the latter's MBC was higher than that of $\mathbf{B}-$ 12 and B-13 by 2 or 3 times, respectively (Table 2). For the next experiments we have selected B-12 and B-13 because B-10 and B-11 are already known natural compounds.

Table 1. Minimal Inhibitory Concentration of butyrolactones against $S$. gordonii by agar dilution

\begin{tabular}{cc}
\hline & \\
\hline Compound & MIC $(\boldsymbol{\mu g} / \mathbf{m L})$ \\
\hline B-1 & 300 \\
B-2 & $>300$ \\
B-3 & 300 \\
B-4 & $>300$ \\
B-5 & $>300$ \\
B-6 & $>300$ \\
B-7 & $>300$ \\
B-8 & 150 \\
B-9 & 150 \\
B-10 & 90 \\
B-11 & 90 \\
B-12 & 200 \\
B-13 & $>300$ \\
Doxycycline & 0.41 \\
\hline
\end{tabular}


Table 2. Minimal inhibitory and bactericidal concentrations of butyrolactones against $S$. gordonii by broth microdilution

\begin{tabular}{ccc}
\hline Compound & MIC $(\boldsymbol{\mu g} / \mathbf{m L})$ & MBC $(\boldsymbol{\mu g} / \mathbf{m L})$ \\
\hline B-1 & 150 & 300 \\
B-2 & 75 & 150 \\
B-3 & 150 & 300 \\
B-4 & 75 & 75 \\
B-5 & 75 & 150 \\
B-6 & 75 & 75 \\
B-7 & $>300$ & $>300$ \\
B-8 & 150 & $>300$ \\
B-9 & 150 & $>300$ \\
B-10 & 4.69 & 18.75 \\
B-11 & 4.69 & 18.75 \\
B-12 & 9.38 & 18.75 \\
B-13 & 9.38 & 9.38 \\
Doxycycline & 0.51 & 32.80 \\
\hline
\end{tabular}

\subsubsection{Cytotoxicity}

B-10 and B-11 were already described so we have chosen B-12 and B-13 to check their cytotoxicity. The viability of gingival epithelial cells, Ca9-22, and macrophage-like cells, THP-1, was evaluated by LDH and MTT assays (Fig. 4A, 4B).

\subsubsection{LDH assay}

The positive control, Triton $1 \%$, was considered as the maximum with 100 percent cytotoxicity (Fig. 4A). Cells alone displayed 9 and $18 \%$ of LDH release from Ca9-22 and THP-1, respectively. No significant difference was displayed between the cells treated with the compounds and the cells alone showing around the same percentages of cell death. Regarding Ca9-22, 9.6 and $12 \%$ were found for B-12, B-13, respectively. With the same order, 20 and 10\% of cell death were registered for THP-1 (Fig. 4A).

\subsubsection{MTT assay}

Cells alone were considered the maximum with $100 \%$ cell viability (Fig. 4B). Triton $1 \%$ was the positive control which showed a significant different result decreasing the cell population into around 3\% for both types of cells. The compounds were fluctuating in a very close range around $100 \%$ and their activities were not significantly different from those against the cells alone. With respect to Ca9-22, 100 and 96\% were displayed by B-12, B-13, respectively. Following the same pattern, 107 and $106 \%$ were found for THP-1 (Fig. 4B).

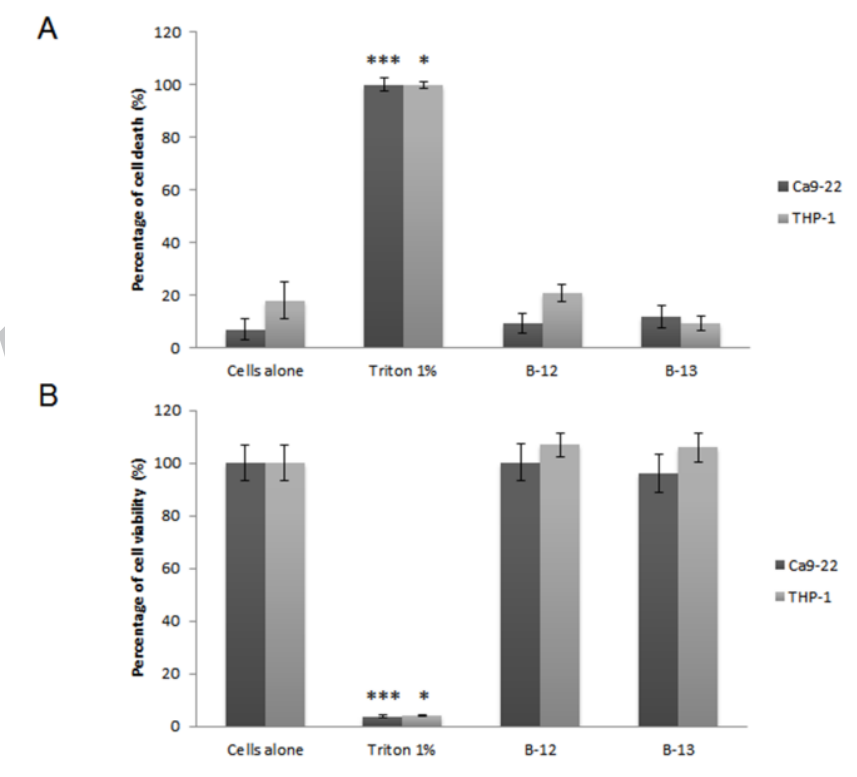




\section{Structure-activity relationships}

To analyze structure-activity relationships, four structural components were considered: the saturation of the $\mathrm{C}_{3}-\mathrm{C}_{4}$ bond, the nature of the substituent (X) and (Y) at the $\mathrm{C}_{3}$ and $\mathrm{C}_{4}$ position respectively, and the length of the alkyl chain (R) (Fig. 5).

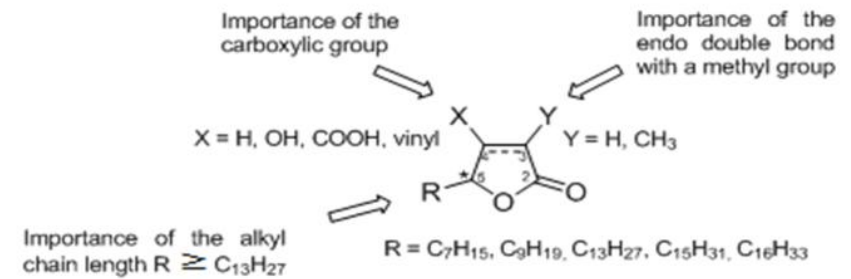

Figure 5. Pharmacomodulation

Starting with the Agar dilution assay, the MIC was controlled by the length of the $\mathrm{R}$ alkyl chain. As the length of $\mathrm{R}$ increased, the activity increased. This was observed between $\mathrm{C}_{9} \mathrm{H}_{19}$ chain compounds $\mathbf{B}-\mathbf{8}$ and $\mathbf{B - 9}$, which had $\mathrm{MIC}=150 \mu \mathrm{g} / \mathrm{mL}$ and $\mathrm{C}_{13} \mathrm{H}_{27}$ chain counterparts or lichesterinic acids (B-10 and B-11), which had MIC $=90 \mu \mathrm{g} / \mathrm{mL}$ (Table 1). Hence, we decided to test shorter and longer chains to confirm our hypothesis. The $\mathrm{C}_{7} \mathrm{H}_{15}$ chain compound $\mathbf{B}-\mathbf{7}$, as well as $\mathbf{B}-\mathbf{1 3}$, with the longest chain $\mathrm{C}_{16} \mathrm{H}_{33}$, didn't show any activity at the highest concentration tested. But, B-12 which was shorter than B-13 by only 1 carbon atom, showed an MIC $=200$ $\mu \mathrm{g} / \mathrm{mL}$. This was interpreted as that the length of the chain plays an important role in its activity where there is an optimum length of 13 carbon atoms which has the highest potential. As the chain length increases or decreases, the activity decreases as well (Table 1).

In broth microdilution assay, all of the compounds were found active except B-7 and exhibited better activity than in solid medium assay (Table 2). This discrepancy between the two media was also shown by Guzman et al. They screened natural products from Columbian plants against Mycobacterium tuberculosis and they obtained different activity between the two media. ${ }^{19}$ Therefore, we can propose that butyrolactones can move more freely due to their lipophilicity and inhibit more efficiently in liquid medium compared to the other different physiological solid state, where the bacteria are confined to the surface. The liquid results confirm the hypothesis of being $\mathrm{C}_{13} \mathrm{H}_{27}$ chain is the optimum length. B-7 with a $\mathrm{C}_{7} \mathrm{H}_{15}$ alkyl group did not show any activity and the effect decreased when the chain length increased. Comparing to $\mathbf{B - 1 0}$, MIC increased to be $9.38 \mu \mathrm{g} / \mathrm{mL}$ for $\mathbf{B - 1 2}$ but the MBC remains the same. Then, when the chain length increases more to be 16 carbon atoms, B-13 showed the same MIC as B-12 but its MBC was the strongest to exhibit a surprising effect that the liquid medium owns. The latter elects an optimum chain length of 13 carbon atoms for the best inhibition but the killing effect increases as the $\mathrm{R}$ chain increases in length since their lipophilicity increases as well. This chain length contribution was discussed by Yang et al where they tested the derivatives of 8-alkylberberine against gram-positive and gram-negative strains to find an optimum length of 8 carbon atoms. Shorter or longer chains showed lowering in the antibacterial activity. They also mentioned that gram-positive strains were more susceptible to these derivatives. ${ }^{20}$ It can be proposed that the saturated chain, R, may be involved in the butyrolactones mechanism of action. The optimum length hypothesis was also supported by comparing other compounds which can be grouped into 3 couples having the same main structure differing only in the length of the $\mathrm{R}$ chain, B-1/B-2, B-3/B-4 and B-5/B6, where when the length increased to 13 carbon atoms the activity increased. MIC and MBC decreased by half comparing $\mathbf{B}-\mathbf{1}$ to $\mathbf{B}-\mathbf{2}$, from 150 and $300 \mu \mathrm{g} / \mathrm{mL}$ for $\mathbf{B}-1$ into 75 and $150 \mu \mathrm{g} / \mathrm{mL}$ for B-2, respectively. Also, the other couples were displaying the same effect. We can see clearly that MIC and MBC decreased from 150 and $300 \mu \mathrm{g} / \mathrm{mL}$ for B-3 and B-5 into $75 \mu \mathrm{g} / \mathrm{mL}$ for B-4 and B-6, respectively. So, the activity is better regarding the couples, B-3/B-4 and $\mathbf{B - 5 / \mathbf { B } - 6}$, than the first couple, B-1/B-2, highlighting the drawback of the introduction of a hydrophilic group for the antibacterial activity of these butyrolactones. We can also notice that the enantiomers showed the same antibacterial effect comparing the value between B-8 and B-9 and B-10 and B-11.

In addition to the $\mathrm{R}$ chain, substitution of different functional groups at $\mathrm{C}_{4}$ position constitutes a second factor affecting the antibacterial activity. These groups divided our compounds into four classes. The first class, $\mathbf{B}-\mathbf{1}$ and $\mathbf{B}-\mathbf{2}$, comprised a hydroxyl group, $\mathrm{OH}$, the second class, B-3 and B-4, comprised a double bond in the ring with no substitutions, the third class, B-5 and B-6, possessed a vinyl group with a saturated ring and finally, the fourth class, B-8, B-9, B-10, B-11, B-12, and B-13, contained an unsaturated ring with two substituents, carboxyl and methyl groups. Since the highest activity was demonstrated for the last class, this suggests that the carboxyl group may stand behind this potency. The importance of this functional group was mentioned by Sebastianes et al who tested the antibacterial activity of a fungal compound, 3-hydroxy propionic acid, 3-HPA, against Staphylococcus aureus and Salmonella typhi. Indeed, 3-HPA showed relevant antibacterial activity against the tested strains. When it was esterified to produce 3-hydroxypropanoic ethyl ester, no antimicrobial activity was registered. ${ }^{21}$ This gives a complementary idea for the probable underpinning mechanism of action in which the carboxylic group and the $\mathrm{R}$ chain could be implicated (Fig. 5). Moreover, these butyrolactones have a similar structure to the $\gamma$-butyrolactone autoregulators described formerly. The latter are produced by the gram-positive Streptomyces genus and they regulate the DNA binding activity of cognate receptor proteins triggering antibiotic production as mentioned by Kitani et al. ${ }^{22}$ Hence, lichesterinic acid and its analogues may modulate the DNA binding activity of some proteins. 


\section{Conclusions}

To conclude, all butyrolactone derivatives were synthesized in good yield with an efficient enantioselective strategy. All compounds were then screened for their antibacterial activity against $S$. gordonii in solid and liquid media using agar dilution and broth microdilution methods, respectively. The compounds have shown a stronger activity in the liquid medium than in the solid one where only B-7 was found not active. The alkyl chain of 13 carbons showed the best inhibitory activity with an MIC of $4.69 \mu \mathrm{g} / \mathrm{mL}$. Among the derivatives, B-12 and B-13 were the best promising compounds registering a better bactericidal activity than the reference antibiotic used, doxycycline, by 2 or 3 times, respectively. This chain alongside the carboxyl functional group may be involved in their mechanism of action. Finally, B-12 and B-13 were evaluated for their cytotoxicity against human gingival epithelial cells, Ca9-22, and macrophages, THP-1, and found not toxic. This gives a bright hope to continue with these two butyrolactones into their antibiofilm activity for their graduation as new oral antibiotic agents. These new compounds are capable to inhibit S. gordonii which may block the successive steps leading to oral complications, thus, a safe prevention rather than a risky late treatment after biofilm formation.

\section{Experimental}

\subsection{Chemistry}

All reagents of high quality were purchased from commercial suppliers and used without further purification. Melting points were recorded on a Kofler Leica VMHB melting point apparatus and are uncorrected. IR spectra were obtained with PerkinElmer UATR Two infrared spectrophotometer. ${ }^{1} \mathrm{H}(300 \mathrm{MHz})$ and ${ }^{13} \mathrm{C}(75 \mathrm{MHz}) \mathrm{NMR}$ spectra were performed on a Bruker DMX 300 spectrometer. Chemical shifts were referenced to the residual solvent signal $\left(\mathrm{CDCl}_{3}: \delta_{\mathrm{H}}=7.26, \delta_{\mathrm{C}}=77.0\right)$. The $\delta$ values are given in parts per million $(\mathrm{ppm})$, and the coupling constants $(J$ values) are given in Hertz $(\mathrm{Hz})$. The multiplicity of the signals is reported as $\mathrm{s}$ (singlet), $\mathrm{d}$ (doublet), t (triplet), q (quadruplet), m (multiplet). ESI-HRMS were carried out on a MICROMASS ZabspecTOF spectrometer for electrospray ionization at the CRMPO (Centre Régional de Mesures Physiques de l'Ouest), University of Rennes 1 . Elemental analyses were performed on a microanalysor Flash EA1112 CHNS/O Thermo Electron at the CRMPO. Optical rotations were measured on a Perkin Elmer Model 341 polarimeter at $20{ }^{\circ} \mathrm{C}$ using thermostable optical glass cell ( $1 \mathrm{dm}$ path length and $c$ in $\left.\mathrm{g} / 100 \mathrm{~mL}\right)$. The ee values were determined by chiral LC with a TSP Spectra System UV2000 and P1000 XR apparatus with a CHIRALPACK® IC or IA column. Reactions were monitored by TLC on Merk 60 F254 $(0.25 \mathrm{~mm})$ plates which were visualized by UV detection or sprayed with vanilline or $\mathrm{KMNO}_{4}$ solutions, then heated.

\subsubsection{General procedures for compounds 1a-e}

A mixture of the appropriate aldehyde $(28.1 \mathrm{mmol})$, monoethyl malonate $(3.32 \mathrm{~mL}, 3.72 \mathrm{~g}, 28.1 \mathrm{mmol}, 1.0 \mathrm{eq}$.$) and NEt 3$ (3.92 mL, $2.85 \mathrm{~g}, 28.1 \mathrm{mmol}, 1.0 \mathrm{eq}$.) was heated at $90-95^{\circ} \mathrm{C}$ under argon atmosphere. After stirring overnight, the reaction mixture was cooled at room temperature and poured at $0{ }^{\circ} \mathrm{C}$ into an aq. $\mathrm{H}_{2} \mathrm{SO}_{4}$ solution $(20 \%, 100 \mathrm{~mL})$. The organic phase was separated and the aqueous phase was extracted with diethyl ether $(3 \times 100 \mathrm{~mL})$. The combined organic phases were dried with $\mathrm{MgSO}_{4}$. After filtration, the solution was concentrated under vacuum to give quantitatively the $\beta, \gamma$-unsaturated carboxylic ester. Then a mixture of $\beta, \gamma$-unsaturated carboxylic ester $(28.1 \mathrm{mmol}), \mathrm{AD}$ mix- $\alpha \circledR(39.34 \mathrm{~g})$, methanesulfonamide $(2.67 \mathrm{~g}, 28.1 \mathrm{mmol}, 1.0$ eq.) was added to a 1:1 mixture of $t \mathrm{BuOH}$ and $\mathrm{H}_{2} \mathrm{O}(180 \mathrm{~mL})$ at $0{ }^{\circ} \mathrm{C}$. After $40 \mathrm{~h}$ the reaction was quenched by adding a satd. aqueous solution of $\mathrm{Na}_{2} \mathrm{SO}_{3}(100 \mathrm{~mL})$, this solution was stirred for $1 \mathrm{~h}$ before extraction with diethyl ether $(3 \times 50 \mathrm{~mL})$. The combined organic layers were dried with $\mathrm{MgSO}_{4}$ and concentrated under vacuum. The residue was purified by chromatography on silicagel using ethyl acetate/petroleum ether $2: 8$ and then $4: 6$ as eluents.

5.1.1.1. (4S,5S)-5-heptyl-4-hydroxy-dihydrofuran-2(3H)-one (4S,5S-1a).

Yield: $64 \%$; white solid; m.p. $75{ }^{\circ} \mathrm{C} . R_{\mathrm{f}}=0.26$ (petroleum ether/ethyl acetate 6:4). $[\alpha]_{\mathrm{D}}=-47.6\left(c 1.07, \mathrm{CHCl}_{3}\right) .{ }^{1} \mathrm{H}$ NMR $\left(\mathrm{CDCl}_{3}, 300 \mathrm{MHz}\right) \delta 0.89(\mathrm{t}, J=6.2 \mathrm{~Hz}, 3 \mathrm{H}), 1.28-1.93$ $(\mathrm{m}, 12 \mathrm{H}), 2.55(\mathrm{~d}, J=17.7 \mathrm{~Hz}, 1 \mathrm{H}), 2.80(\mathrm{dd}, J=5.4 \mathrm{~Hz}$ and $J=17.7 \mathrm{~Hz}, 1 \mathrm{H}), 4.34-4.40(\mathrm{~m}, 1 \mathrm{H}), 4.46-4.48(\mathrm{~m}, 1 \mathrm{H}) \mathrm{ppm} .{ }^{13} \mathrm{C} \mathrm{NMR}$ $\left(\mathrm{CDCl}_{3}, 75 \mathrm{MHz}\right) \delta 14.2,22.7,25.7,28.4,29.2,29.5,31.9,39.6,69.1,85.3,176.4$ ppm. HRMS (ESI, m/z) : Calcd. for $\mathrm{C}_{11} \mathrm{H}_{20} \mathrm{O}_{3} \mathrm{Na}$ : 223.13101, found $[\mathrm{M}+\mathrm{Na}]^{+}: 223.1309$.

5.1.1.2. (4S,5S)-4-hydroxy-5-nonyl-dihydrofuran-2(3H)-one (4S,5S-1b). This compound was prepared as published ${ }^{23}$. Yield $=63 \%$. $[\alpha]_{\mathrm{D}}=-38.9\left(c 1.15, \mathrm{CHCl}_{3}\right)$. HRMS (ESI, m/z): Calcd. for $\mathrm{C}_{13} \mathrm{H}_{24} \mathrm{O}_{3} \mathrm{Na}: 251.16231$, found $[\mathrm{M}+\mathrm{Na}]^{+}: 251.1618$.

5.1.1.3. (4R,5R)-4-hydroxy-5-nonyl-dihydrofuran-2(3H)-one (4R,5R-1b) $(B-1)$.

Yield $=63 \%$; white solid; m.p. $69^{\circ} \mathrm{C} . \mathrm{R}_{\mathrm{f}}$ (petroleum ether/ethyl acetate 8:2) $=0.10 .[\alpha]_{\mathrm{D}}=+44.2\left(c 1.07, \mathrm{CHCl}_{3}\right) .{ }^{1} \mathrm{H} \mathrm{NMR}\left(\mathrm{CDCl}_{3}, 300 \mathrm{MHz}\right) \delta 0.88(\mathrm{t}, J=6.7 \mathrm{~Hz}, 3 \mathrm{H}), 1.27-$ $1.95(\mathrm{~m}, 16 \mathrm{H}), 2.55(\mathrm{dd}, J=0.9 \mathrm{~Hz}$ and $J=17.7 \mathrm{~Hz}, 1 \mathrm{H}), 2.80(\mathrm{dd}, J=5.4 \mathrm{~Hz}$ and $J=17.7 \mathrm{~Hz}, 1 \mathrm{H}), 4.33-4.39(\mathrm{~m}, 1 \mathrm{H}), 4.46-4.51(\mathrm{~m}$, $1 \mathrm{H}) \mathrm{ppm} .{ }^{13} \mathrm{C} \mathrm{NMR}\left(\mathrm{CDCl}_{3}, 75 \mathrm{MHz}\right) \delta 13.4,22.0,24.9,27.6,28.6,28.7,28.8,31.2,38.8,68.3,84.4,175.4 \mathrm{ppm}$. IR (ATR) 3466, 2952, 2922, 2850, 1740. HRMS (ESI, m/z): Calcd. for $\mathrm{C}_{13} \mathrm{H}_{24} \mathrm{O}_{3} \mathrm{Na}$ : 251.1623, found [M+Na] $]^{+}: 251.1626$.

5.1.1.4. (4S,5S)-4-hydroxy-5-tridecyl-dihydrofuran-2(3H)-one (4S,5S-1c).

This compound was prepared as published. ${ }^{17}$ Yield $=61 \%$. $[\alpha]_{\mathrm{D}}=-37.1\left(c 1.07, \mathrm{CHCl}_{3}\right)$. HRMS (ESI, m/z): Calcd. for $\mathrm{C}_{17} \mathrm{H}_{32} \mathrm{O}_{3} \mathrm{Na}: 307.2249$, found $[\mathrm{M}+\mathrm{Na}]^{+}: 307.2244$.

5.1.1.5. (4R,5R)-4-hydroxy-5-tridecyl-dihydrofuran-2(3H)-one (4R,5R-1c) (B-2).

This compound was prepared as published. ${ }^{17}$ Yield $=61 \%$. $[\alpha]_{\mathrm{D}}=+18.5\left(c 1.04, \mathrm{CHCl}_{3}\right)$. HRMS (ESI, m/z): Calcd. for $\mathrm{C}_{17} \mathrm{H}_{32} \mathrm{O}_{3} \mathrm{Na}: 307.2249$, found $[\mathrm{M}+\mathrm{Na}]^{+}$: 307.2249 .

5.1.1.6. (4S,5S)-4-hydroxy-5-pentadecyl-dihydrofuran-2(3H)-one (4S,5S-1d). Yield $=53 \%$; white solid; m.p. $96{ }^{\circ} \mathrm{C}$. $\mathrm{R}_{\mathrm{f}}$ (petroleum ether/ethyl acetate 8:2) $=0.11 .[\alpha]_{\mathrm{D}}=-32.9\left(c 0.93, \mathrm{CHCl}_{3}\right) .{ }^{1} \mathrm{H} \mathrm{NMR}\left(\mathrm{CDCl}_{3}, 300 \mathrm{MHz}\right) \delta 0.88(\mathrm{t}, J=6.7 \mathrm{~Hz}, 3 \mathrm{H}), 1.26-$ $1.93(\mathrm{~m}, 29 \mathrm{H}), 2.56(\mathrm{dd}, J=0.8 \mathrm{~Hz}$ and $J=17.7 \mathrm{~Hz}, 1 \mathrm{H}), 2.80(\mathrm{dd}, J=5.4 \mathrm{~Hz}$ and $J=17.5 \mathrm{~Hz}, 1 \mathrm{H}), 4.34-4.40(\mathrm{~m}, 1 \mathrm{H}), 4.46-4.49(\mathrm{~m}$, 
1H) ppm. ${ }^{13} \mathrm{C} \mathrm{NMR}\left(\mathrm{CDCl}_{3}, 75 \mathrm{MHz}\right) \delta$ 14.3, 22.8, 25.7, 28.4, 29.5, 29.6, 29.7, 29.8, 29.9 32.1, 39.6, 69.2, 85.1, 176.05 ppm. HRMS (ESI, m/z) : Calcd. for $\mathrm{C}_{19} \mathrm{H}_{36} \mathrm{O}_{3} \mathrm{Na}: 335.25622$, found $[\mathrm{M}+\mathrm{Na}]^{+}: 335.2559$.

5.1.1.7. (4S,5S)-5-hexadecyl-4-hydroxy-dihydrofuran-2(3H)-one (4S,5S-1e). Yield $=52 \%$; white solid; m.p. $99 \quad{ }^{\circ} \mathrm{C}$. $\mathrm{R}_{\mathrm{f}}$ (petroleum ether/ethyl acetate 8:2) $=0.10 .[\alpha]_{\mathrm{D}}=-34.6\left(c 1.04, \mathrm{CHCl}_{3}\right) .{ }^{1} \mathrm{H} \mathrm{NMR}\left(\mathrm{CDCl}_{3}, 300 \mathrm{MHz}\right) \delta 0.88(\mathrm{t}, J=6.6 \mathrm{~Hz}, 3 \mathrm{H}), 1.25-$ $1.93(\mathrm{~m}, 30 \mathrm{H}), 2.56(\mathrm{~d}, J=17.7 \mathrm{~Hz}, 1 \mathrm{H}), 2.80(\mathrm{dd}, J=5.4 \mathrm{~Hz}$ and $J=17.7 \mathrm{~Hz}, 1 \mathrm{H}), 4.34-4.39(\mathrm{~m}, 1 \mathrm{H}), 4.46-4.49(\mathrm{~m}, 1 \mathrm{H}) \mathrm{ppm} .{ }^{13} \mathrm{C}$ $\operatorname{NMR}\left(\mathrm{CDCl}_{3}, 75 \mathrm{MHz}\right) \delta 14.3,22.8,25.7,28.4,29.5,29.6,29.7,29.8,32.1,39.6,43.6,69.2,85.0,175.8$; HRMS (ESI, m/z): Calcd. for $\mathrm{C}_{20} \mathrm{H}_{38} \mathrm{O}_{3} \mathrm{Na}: 349.2719$, found $[\mathrm{M}+\mathrm{Na}]^{+}: 349.2719$.

\subsubsection{General procedure for compounds $2 \mathrm{a}-\mathrm{e}$}

At $0{ }^{\circ} \mathrm{C}$ under argon atmosphere $\mathrm{NEt}_{3}(5.33 \mathrm{~mL}, 3.87 \mathrm{~g}, 38.2 \mathrm{mmol}, 2.2 \mathrm{eq}$.) and methanesulfonyl chloride $(1.48 \mathrm{~mL}, 2.19 \mathrm{~g}, 19.1$ mmol, 1.1 eq.) were added dropwise to a solution of hydroxylactone 1 (17.4 mmol) in anhydrous $\mathrm{CH}_{2} \mathrm{Cl}_{2}(85 \mathrm{~mL})$. After sttirring for $1 \mathrm{~h}$ the reaction was quenched by adding a satd. aqueous solution of $\mathrm{NH}_{4} \mathrm{Cl}(150 \mathrm{~mL})$. The organic phase was separated and the aqueous phase was extracted with diethyl ether $\left(3 \times 50 \mathrm{~mL}\right.$ ). The combined organic layers were dried with $\mathrm{MgSO}_{4}$ and concentrated under vacuum. The residue was purified by chromatography on silicagel using diethyl ether/petroleum ether 1:4 as eluents.

5.1.2.1. (S)-5-heptylfuran-2(5H)-one (5S-2a). $\quad$ Yield $=94 \%$; colorless oil. $R_{\mathrm{f}}$ (petroleum ether/diethyl ether $\left.8: 2\right)=0.17 .[\alpha]_{\mathrm{D}}=$ $+77.8\left(c 1.21, \mathrm{CHCl}_{3}\right) .{ }^{1} \mathrm{H}$ NMR $\left(\mathrm{CDCl}_{3}, 300 \mathrm{MHz}\right) \delta 0.88(\mathrm{t}, J=6.7 \mathrm{~Hz}, 3 \mathrm{H}), 1.28-1.83(\mathrm{~m}, 12 \mathrm{H}), 5.02-5.07(\mathrm{~m}, 1 \mathrm{H}), 6.11(\mathrm{dd}, J=$ $2.0 \mathrm{~Hz}$ and $J=5.7 \mathrm{~Hz}, 1 \mathrm{H}), 7.46(\mathrm{dd}, J=1.45 \mathrm{~Hz}$ and $J=5.7 \mathrm{~Hz}, 1 \mathrm{H}) \mathrm{ppm} .{ }^{13} \mathrm{C} \mathrm{NMR}\left(\mathrm{CDCl}_{3}, 75 \mathrm{MHz}\right) \delta 14.2,22.7,25.1,29.1,29.3$, 31.8, 33.3, 83.6, 121.6, 156.5, 173.3 ppm. HRMS (ESI, m/z): Calcd. for $\mathrm{C}_{11} \mathrm{H}_{18} \mathrm{O}_{2} \mathrm{Na}: 205.1205$, found [M+Na] ${ }^{+}: 205.1203$.

5.1.2.2. (S)-5-nonylfuran-2(5H)-one (5S-2b).

This compound was prepared as published. ${ }^{23}$ Yield $=94 \% .[\alpha]_{\mathrm{D}}=+63.5(c$ 0.94, $\mathrm{CHCl}_{3}$ ). HRMS (ESI, m/z): Calcd. for $\mathrm{C}_{13} \mathrm{H}_{22} \mathrm{O}_{2} \mathrm{Na}$ : 233.1518, found [M+Na] ${ }^{+}: 233.1517$.

5.1.2.3. (R)-5-nonylfuran-2(5H)-one (5R-2b) (B-3). Yield $=91 \%$; colorless oil. $R_{\mathrm{f}}\left(\right.$ petroleum ether/diethyl ether 8:2) $=0.16$. $[\alpha]_{\mathrm{D}}=-$ $62.7\left(c\right.$ 1.17, $\left.\mathrm{CHCl}_{3}\right)$. ${ }^{1} \mathrm{H} \mathrm{NMR}\left(\mathrm{CDCl}_{3}, 300 \mathrm{MHz}\right) \delta 0.88(\mathrm{t}, J=6.7 \mathrm{~Hz}, 3 \mathrm{H}), 1.26-1.82(\mathrm{~m}, 16 \mathrm{H}), 5.01-5.07(\mathrm{~m}, 1 \mathrm{H}), 6.11(\mathrm{dd}, J=$ $2.0 \mathrm{~Hz}$ and $J=5.7 \mathrm{~Hz}, 1 \mathrm{H}), 7.46(\mathrm{dd}, J=1.5 \mathrm{~Hz}$ and $J=5.7 \mathrm{~Hz}, 1 \mathrm{H}) \mathrm{ppm} .{ }^{13} \mathrm{C}$ NMR $\left(\mathrm{CDCl}_{3}, 75 \mathrm{MHz}\right) \delta 14.4,23.0,25.3,29.6,29.62$, 29.7, 29.8, 32.2, 33.5, 83.8, 121.8, 156.7, 173.5 ppm. IR (ATR) 2923, 2853, 1744. HRMS (ESI, m/z): Calcd. for $\mathrm{C}_{13} \mathrm{H}_{22} \mathrm{O}_{2} \mathrm{Na}$ 233.1518 , found $[\mathrm{M}+\mathrm{Na}]^{+}: 233.1519$.

5.1.2.4. (S)-5-tridecylfuran-2(5H)-one (5S-2c). This compound was prepared as published. ${ }^{17}$ Yield $=77 \%$. $[\alpha]_{\mathrm{D}}=+54.2(c$ 1.01, $\mathrm{CHCl}_{3}$ ). HRMS (ESI, m/z): Calcd. for $\mathrm{C}_{17} \mathrm{H}_{30} \mathrm{O}_{2} \mathrm{Na}: 289.2144$, found $[\mathrm{M}+\mathrm{Na}]^{+}: 289.2138$.

5.1.2.5. (R)-5-tridecylfuran-2(5H)-one (5R-2c) (B-4). This compound was prepared as published. ${ }^{17}$ Yield $=81 \% .[\alpha]_{\mathrm{D}}=-57.2(c 1.09$, $\mathrm{CHCl}_{3}$ ), HRMS (ESI, m/z): Calcd. for $\mathrm{C}_{17} \mathrm{H}_{30} \mathrm{O}_{2} \mathrm{Na}: 289.2144$, found [M+Na] $]^{+}: 289.2144$.

5.1.2.6. (S)-5-pentadecylfuran-2(5H)-one (5S-2d). Yield $=75 \%$; white solid; m.p. $67{ }^{\circ} \mathrm{C} . \mathrm{R}_{\mathrm{f}}$ (petroleum ether/ethyl acetate 7:3) $=$ 0.78. $[\alpha]_{\mathrm{D}}=+48.9\left(c 1.17, \mathrm{CHCl}_{3}\right) .{ }^{1} \mathrm{H} \mathrm{NMR}\left(\mathrm{CDCl}_{3}, 300 \mathrm{MHz}\right) \delta 0.88(\mathrm{t}, J=6.7 \mathrm{~Hz}, 3 \mathrm{H}), 1.26-1.83(\mathrm{~m}, 28 \mathrm{H}), 5.01-5.07(\mathrm{~m}, 1 \mathrm{H})$, $6.10(\mathrm{dd}, J=1.9 \mathrm{~Hz}$ and $J=5.7 \mathrm{~Hz}, 1 \mathrm{H}), 7.46(\mathrm{dd}, J=1.4 \mathrm{~Hz}$ and $J=5.7 \mathrm{~Hz}, 1 \mathrm{H}) \mathrm{ppm} .{ }^{13} \mathrm{C} \mathrm{NMR}\left(\mathrm{CDCl}_{3}, 75 \mathrm{MHz}\right) \delta 14.2,22.8,25.1$, 29.4, 29.5, 29.6, 29.7, 29.8, 32.0, 33.3, 83.6, 121.6, 156.5, 173.3 ppm. HRMS (ESI, m/z) : Calcd. for $\mathrm{C}_{19} \mathrm{H}_{34} \mathrm{O}_{2} \mathrm{Na}_{2}: 317.2457$, found $[\mathrm{M}+\mathrm{Na}]^{+}: 317.2456$.

5.1.2.7. (S)-5-hexadecylfuran-2(5H)-one (5S-2e). $\quad$ Yield $=91 \%$; white solid; m.p. $74{ }^{\circ} \mathrm{C} . \mathrm{R}_{\mathrm{f}}$ (petroleum ether/diethyl ether 8:2) $=$ 0.26. $[\alpha]_{\mathrm{D}}=+50.7\left(c 1.04, \mathrm{CHCl}_{3}\right) .{ }^{1} \mathrm{H} \mathrm{NMR}\left(\mathrm{CDCl}_{3}, 300 \mathrm{MHz}\right) \delta 0.88(\mathrm{t}, J=6.5 \mathrm{~Hz}, 3 \mathrm{H}), 1.25-1.83(\mathrm{~m}, 30 \mathrm{H}), 5.01-5.06(\mathrm{~m}, 1 \mathrm{H}), 6.11$ $(\mathrm{dd}, J=2.0 \mathrm{~Hz}$ and $J=5.7 \mathrm{~Hz}, 1 \mathrm{H}), 7.45(\mathrm{dd}, J=1.4 \mathrm{~Hz}$ and $J=5.7 \mathrm{~Hz}, 1 \mathrm{H}) \mathrm{ppm} .{ }^{13} \mathrm{C} \mathrm{NMR}\left(\mathrm{CDCl}_{3}, 75 \mathrm{MHz}\right) \delta 14.3,22.8,25.1,29.4$, 29.5, 29.6, 29.7, 29.8, 32.1, 33.3, 83.6, 121.6, 156.4, 173.3 ppm. HRMS (ESI, m/z): Calcd. for $\mathrm{C}_{20} \mathrm{H}_{36} \mathrm{O}_{2} \mathrm{Na}: 331.2613$, found [M+Na] $]^{+}$ 331.2613 .

\subsubsection{General procedure for compounds 3a-e}

To a $-78{ }^{\circ} \mathrm{C}$ solution of $\mathrm{CuI}(15.41 \mathrm{~g}, 80.9 \mathrm{mmol}, 5.0 \mathrm{eq}$.) in anhydrous tetrahydrofuran (THF, $120 \mathrm{~mL})$ was slowly added a solution of methyl lithium $(50.6 \mathrm{~mL}, 80.9 \mathrm{mmol}$ of $1.6 \mathrm{M}, 5.0 \mathrm{eq}$.). The suspension was allowed to reach $\mathrm{rt}$ during $15 \mathrm{~min}$ and then cooled to -78 ${ }^{\circ} \mathrm{C}$ and vinyl magnesium bromide $\left(80.9 \mathrm{~mL}, 80.9 \mathrm{mmol}\right.$ of $1 \mathrm{M}, 5.0$ eq.) was added. The mixture was stirred for $15 \mathrm{~min}$ at $-78{ }^{\circ} \mathrm{C}$ and then butenolide $2(16.2 \mathrm{mmol})$ in THF $(20 \mathrm{~mL})$ was added dropwise. The resulting black solution was allowed to warm at $\mathrm{rt}$ and was stirred for $2 \mathrm{~h}$. Then the mixture was poured into $500 \mathrm{~mL}$ of vigorously stirred satd. aqueous $\mathrm{NH}_{4} \mathrm{Cl}$ solution. The $\mathrm{pH}$ of solution was adjusted to 8-10 by addition of conc $\mathrm{NH}_{4} \mathrm{OH}$. The mixture was stirred at $\mathrm{rt}$ for $1.5 \mathrm{~h}$ until all the copper salts had dissolved. The blue solution was extracted with diethyl ether, the organic phase was filtered through celite and then washed with a solution of ethylenediamine $\left(50 \mathrm{~mL}\right.$ with $\left.450 \mathrm{~mL} \mathrm{H}_{2} \mathrm{O}\right)$. The organic layer was dried with $\mathrm{MgSO}_{4}$ and concentrated under vacuum. The residue was purified by chromatography on silicagel using petroleum ether/ethyl acetate 9.5:0.5 as eluents.

5.1.3.1. (4S,5S)-5-heptyl-4-vinyl-dihydrofuran-2(3H)-one (4S,5S-3a). Yield $=81 \%$; colorless oil. $\mathrm{R}_{\mathrm{f}}$ (petroleum ether/ethyl acetate 9.5:0.5) $=0.27 .[\alpha]_{\mathrm{D}}=-63.1\left(c 1.13, \mathrm{CHCl}_{3}\right) .{ }^{1} \mathrm{H} \mathrm{NMR}\left(\mathrm{CDCl}_{3}, 300 \mathrm{MHz}\right) \delta 0.88(\mathrm{t}, J=6.6 \mathrm{~Hz}, 3 \mathrm{H}), 1.28-1.76(\mathrm{~m}, 12 \mathrm{H}), 2.45(\mathrm{dd}, J=$ $10.5 \mathrm{~Hz}$ and $J=17.6 \mathrm{~Hz}, 1 \mathrm{H}), 2.68(\mathrm{dd}, J=8.2 \mathrm{~Hz}$ and $J=17.0 \mathrm{~Hz}, 1 \mathrm{H}), 2.73-2.85(\mathrm{~m}, 1 \mathrm{H}), 4.11-4.18(\mathrm{~m}, 1 \mathrm{H}), 5.14-5.21(\mathrm{~m}, 2 \mathrm{H})$, 5.67-5.79 (m, 1H) ppm. ${ }^{13} \mathrm{C} \mathrm{NMR}\left(\mathrm{CDCl}_{3}, 75 \mathrm{MHz}\right) \delta 14.1,22.6,25.8,29.1,29.3,31.7,33.6,35.5,46.4,84.8,118.0,135.8,175.8 \mathrm{ppm}$. HRMS (ESI, m/z) : Calcd. for $\mathrm{C}_{13} \mathrm{H}_{22} \mathrm{O}_{2} \mathrm{Na}$ : 233.1518, found [M+Na] $]^{+}: 233.1517$. 
5.1.3.2. (4S,5S)-5-nonyl-4-vinyl-dihydrofuran-2(3H)-one (4S,5S-3b). Yield $=62 \%$; colorless oil. $\mathrm{R}_{\mathrm{f}}$ (petroleum ether/ethyl acetate 9.5:0.5 $=0.14 .[\alpha]_{\mathrm{D}}=-54.5\left(c 1.19, \mathrm{CHCl}_{3}\right) .{ }^{1} \mathrm{H} \mathrm{NMR}\left(\mathrm{CDCl}_{3}, 300 \mathrm{MHz}\right) \delta 0.88(\mathrm{t}, J=6.7 \mathrm{~Hz}, 3 \mathrm{H}), 1.26-1.78(\mathrm{~m}, 16 \mathrm{H}), 2.45(\mathrm{dd}, J=$ $10.3 \mathrm{~Hz}$ and $J=16.9 \mathrm{~Hz}, 1 \mathrm{H}), 2.68(\mathrm{dd}, J=8.2 \mathrm{~Hz}$ and $J=16.9 \mathrm{~Hz}, 1 \mathrm{H}), 2.73-2.84(\mathrm{~m}, 1 \mathrm{H}), 4.11-4.17(\mathrm{~m}, 1 \mathrm{H}), 5.15-5.21(\mathrm{~m}, 2 \mathrm{H})$, 5.67-5.78 (m, 1H) ppm. ${ }^{13} \mathrm{C}$ NMR $\left(\mathrm{CDCl}_{3}, 75 \mathrm{MHz}\right) \delta 14.1,22.6,25.7,29.2,29.3,29.4,29.45,31.8,33.6,35.4,46.3,84.8,117.9$, 135.8, 175.8 ppm. HRMS (ESI, m/z) : Calcd. for $\mathrm{C}_{15} \mathrm{H}_{26} \mathrm{O}_{2} \mathrm{Na}: 261.1831$, found $[\mathrm{M}+\mathrm{Na}]^{+}: 261.1832$.

5.1.3.3. (4R,5R)-5-nonyl-4-vinyl-dihydrofuran-2(3H)-one (4R,5R-3b) (B-5). $\quad$ Yield $=70 \%$; colorless oil. $\mathrm{R}_{\mathrm{f}} \quad$ (petroleum ether/ethyl acetate 9.5:0.5) $=0.14 .[\alpha]_{\mathrm{D}}=+55.6\left(c 1.27, \mathrm{CHCl}_{3}\right) .{ }^{1} \mathrm{H} \mathrm{NMR}\left(\mathrm{CDCl}_{3}, 300 \mathrm{MHz}\right) \delta 0.88(\mathrm{t}, J=6.7 \mathrm{~Hz}, 3 \mathrm{H}), 1.26-1.78(\mathrm{~m}$, $16 \mathrm{H}), 2.45(\mathrm{dd}, J=10.3 \mathrm{~Hz}$ and $J=16.9 \mathrm{~Hz}, 1 \mathrm{H}), 2.68(\mathrm{dd}, J=8.2 \mathrm{~Hz}$ and $J=16.9 \mathrm{~Hz}, 1 \mathrm{H}), 2.73-2.84(\mathrm{~m}, 1 \mathrm{H}), 4.11-4.17(\mathrm{~m}, 1 \mathrm{H})$, 5.15-5.21 (m, 2H), 5.67-5.78 (m, 1H) ppm. ${ }^{13} \mathrm{C} \mathrm{NMR}\left(\mathrm{CDCl}_{3}, 75 \mathrm{MHz}\right) \delta 14.1,22.6,25.7,29.2,29.3,29.4,29.5,31.8,33.6,35.4,46.3$, 84.8, 117.9, 135.8, 175.8 ppm. HRMS (ESI, m/z) : Calcd. for $\mathrm{C}_{15} \mathrm{H}_{26} \mathrm{O}_{2} \mathrm{Na}: 261.1831$, found $[\mathrm{M}+\mathrm{Na}]^{+}: 261.1832$.

5.1.3.4. (4S,5S)-5-tridecyl-4-vinyl-dihydrofuran-2(3H)-one $(\mathbf{4 S}, 5 \mathrm{~S}-3 \mathrm{c})$ ). Yield $=77 \%$; white solid; m.p. $48{ }^{\circ} \mathrm{C}$. $\mathrm{R}_{\mathrm{f}}(\mathrm{petroleum}$ ether/ethyl acetate 9:1) $=0.51 .[\alpha]_{\mathrm{D}}=-42.9\left(c 1.20, \mathrm{CHCl}_{3}\right) .{ }^{1} \mathrm{H} \mathrm{NMR}\left(\mathrm{CDCl}_{3}, 300 \mathrm{MHz}\right) \delta 0.88(\mathrm{t}, J=6.5 \mathrm{~Hz}, 3 \mathrm{H}), 1.26-1.80(\mathrm{~m}$, $24 \mathrm{H}), 2.44(\mathrm{dd}, J=10.3 \mathrm{~Hz}$ and $J=16.9 \mathrm{~Hz}, 1 \mathrm{H}), 2.68(\mathrm{dd}, J=8.2 \mathrm{~Hz}$ and $J=16.9 \mathrm{~Hz}, 1 \mathrm{H}), 2.72-2.81(\mathrm{~m}, 1 \mathrm{H}), 4.11-4.17(\mathrm{~m}, 1 \mathrm{H})$, 5.15-5.21 (m, 2H), 5.66-5.78 (m, 1H) ppm. ${ }^{13} \mathrm{C} \mathrm{NMR}\left(\mathrm{CDCl}_{3}, 75 \mathrm{MHz}\right) \delta 14.2,22.8,25.8,29.5,29.6,29.7,29.8,32.0,33.8,35.6,46.5$, 85.0, 118.1, 135.95, 175.9 ppm. HRMS (ESI, m/z) : Calcd. for $\mathrm{C}_{19} \mathrm{H}_{34} \mathrm{O}_{2} \mathrm{Na}: 317.2457$, found $[\mathrm{M}+\mathrm{Na}]^{+}: 317.2456$.

5.1.3.5. (4R,5R)-5-tridecyl-4-vinyl-dihydrofuran-2(3H)-one (4R,5R-3c) (B-6). This compound was prepared as published. ${ }^{24} \mathrm{Yield}^{-}$ $=71 \% .[\alpha]_{\mathrm{D}}=+45.0\left(c 1.11, \mathrm{CHCl}_{3}\right) . \mathrm{HRMS}(\mathrm{ESI}, \mathrm{m} / \mathrm{z}):$ Calcd. for $\mathrm{C}_{19} \mathrm{H}_{34} \mathrm{O}_{2} \mathrm{Na}: 317.2457$, found $[\mathrm{M}+\mathrm{Na}]^{+}: 317.2456$.

5.1.3.6. (4S,5S)-5-pentadecyl-4-vinyl-dihydrofuran-2(3H)-one (4S,5S-3d). $\quad$ Yield $=80 \%$; white $\quad$ solid; m.p. $61 \quad{ }^{\circ} \mathrm{C}$. $\mathrm{R}_{\mathrm{f}}$ (petroleum ether/ethyl acetate 9:1) $=0.43 .[\alpha]_{\mathrm{D}}=-34.6\left(c 1.33, \mathrm{CHCl}_{3}\right) .{ }^{1} \mathrm{H} \mathrm{NMR}\left(\mathrm{CDCl}_{3}, 300 \mathrm{MHz}\right) \delta 0.88(\mathrm{t}, J=6.7 \mathrm{~Hz}, 3 \mathrm{H}), 1.26-$ $1.71(\mathrm{~m}, 28 \mathrm{H}), 2.45(\mathrm{dd}, J=10.4 \mathrm{~Hz}$ and $J=17.0 \mathrm{~Hz}, 1 \mathrm{H}), 2.69(\mathrm{dd}, J=8.2 \mathrm{~Hz}$ and $J=16.9 \mathrm{~Hz}, 1 \mathrm{H}), 2.75-2.81(\mathrm{~m}, 1 \mathrm{H}), 4.11-4.17$ $(\mathrm{m}, 1 \mathrm{H}), 5.15-5.21(\mathrm{~m}, 2 \mathrm{H}), 5.66-5.78(\mathrm{~m}, 1 \mathrm{H}) \mathrm{ppm} .{ }^{13} \mathrm{C} \mathrm{NMR}\left(\mathrm{CDCl}_{3}, 75 \mathrm{MHz}\right) \delta 14.2,22.8,25.8,29.5,29.6,29.7,29.8,32.0,33.7$, 35.6, 46.5, 84.9, 118.1, 135.9, 175.9. HRMS (ESI, m/z) : Calcd. for $\mathrm{C}_{21} \mathrm{H}_{38} \mathrm{O}_{2} \mathrm{Na}: 345.2770$, found [M+Na] $]^{+} 345.2767$.

5.1.3.7. (4S,5S)-5-hexadecyl-4-vinyl-dihydrofuran-2(3H)-one (4S,5S-3e), $\quad$ Yield $=65 \%$; white solid; m.p. $65 \quad{ }^{\circ} \mathrm{C}$. $\mathrm{R}_{\mathrm{f}}$ (petroleum ether/ethyl acetate 9:1) $=0.38 .[\alpha]_{\mathrm{D}}=-41.3\left(\mathrm{c} 1.04, \mathrm{CHCl}_{3}\right) .{ }^{1} \mathrm{H} \mathrm{NMR}\left(\mathrm{CDCl}_{3}, 300 \mathrm{MHz}\right) \delta 0.88(\mathrm{t}, J=6.7 \mathrm{~Hz}, 3 \mathrm{H}), 1.26-$ $1.76(\mathrm{~m}, 30 \mathrm{H}), 2.45(\mathrm{dd}, J=10.3 \mathrm{~Hz}$ and $J=16.9 \mathrm{~Hz}, 1 \mathrm{H}), 2.68(\mathrm{dd}, J=8.2 \mathrm{~Hz}$ and $J=17.0 \mathrm{~Hz}, 1 \mathrm{H}), 2.75-2.84(\mathrm{~m}, 1 \mathrm{H}), 4.11-4.17$ $(\mathrm{m}, 1 \mathrm{H}), 5.15-5.21(\mathrm{~m}, 2 \mathrm{H}), 5.67-5.78(\mathrm{~m}, 1 \mathrm{H}) \mathrm{ppm} .{ }^{13} \mathrm{C} \mathrm{NMR}\left(\mathrm{CDCl}_{3}, 75 \mathrm{MHz}\right) \delta 14.2,22.8,25.8,29.5,29.6,29.7,29.8,32.0,33.8$, 35.6, 46.5, 84.9, 118.1, 135.9, 175.9 ppm. HRMS (ESI, m/z) : Calcd. for $\mathrm{C}_{22} \mathrm{H}_{40} \mathrm{O}_{2} \mathrm{Na}: 359.2926$, found $[\mathrm{M}+\mathrm{Na}]^{+}: 359.2925$.

\subsubsection{General procedure for compounds $4 a-e$}

To a stirred solution at $\mathrm{rt}$ of vinyl lactone $\mathbf{3}(13.1 \mathrm{mmol})$ in a solvent mixture of $\mathrm{CH}_{3} \mathrm{CN} / \mathrm{CCl}_{4} / \mathrm{H}_{2} \mathrm{O}(14: 14: 21 \mathrm{~mL})$ were added NaIO 4 (11.19 g, $52.3 \mathrm{mmol}, 4.0 \mathrm{eq}$;) and $\mathrm{RuCl}_{3}\left(0.27 \mathrm{~g}, 1.31 \mathrm{mmol}, 0.1 \mathrm{eq}\right.$.). After $3 \mathrm{~h}$ at rt, $\mathrm{CH}_{2} \mathrm{Cl}_{2}$ was added and the aq. phase was separated and extracted with $\mathrm{CH}_{2} \mathrm{Cl}_{2}$. The combined organic layers were filtered once through celite and then through silicagel+celite. The filtrate was concentrated under vacuum and the residue was diluted with diethyl ether $(200 \mathrm{~mL})$ and satd. $\mathrm{NaHCO}_{3}$ solution $(200 \mathrm{~mL})$ was added. After separation of the two phases, the aq. phase was acidified with $\mathrm{HCl} 1 \mathrm{M}$ until $\mathrm{pH}=2$. The product was extracted with $\mathrm{CH}_{2} \mathrm{Cl}_{2}$, dried with $\mathrm{MgSO}_{4}$ and concentrated under vacuum to yield the desired compounds in pure form.

5.1.4.1. (2S,3R)-2-heptyl-5-oxo-tetrahydrofuran-3-carboxylic acid (4R,5S-4a). Yield $=80 \%$; white solid; m.p. $110{ }^{\circ} \mathrm{C}$. $\mathrm{R}_{\mathrm{f}}$ $\left(\mathrm{CH}_{2} \mathrm{Cl}_{2} / \mathrm{MeOH} 9: 1\right)=0.48 .[\alpha]_{\mathrm{D}}=-29.2\left(c 1.13 ; \mathrm{CHCl}_{3}\right) .{ }^{1} \mathrm{H} \mathrm{NMR}\left(\mathrm{CDCl}_{3}, 300 \mathrm{MHz}\right) \delta 0.88(\mathrm{t}, J=6.4 \mathrm{~Hz}, 3 \mathrm{H}), 1.28-1.83(\mathrm{~m}, 12 \mathrm{H})$, $2.78-3.00(\mathrm{~m}, 2 \mathrm{H}), 3.07-3.15(\mathrm{~m}, 1 \mathrm{H}), 4.60-4.69(\mathrm{~m}, 1 \mathrm{H}) \mathrm{ppm} .{ }^{13} \mathrm{C} \mathrm{NMR}\left(\mathrm{CDCl}_{3}, 75 \mathrm{MHz}\right) \delta 14.2,22.7,25.3,29.2,29.3,31.8,32.0$, 35.5, 45.5, 82.0, 174.5, 176.4 ppm. HRMS (ESI, m/z) : Calcd. for $\mathrm{C}_{12} \mathrm{H}_{19} \mathrm{O}_{4}: 227.1289$, found [M-H] $]^{-} 227.1290$.

5.1.4.2. (2S,3R)-2-nonyl-5-oxo-tetrahydrofuran-3-carboxylic acid $(\mathbf{4 R}, 5 \mathrm{~S}-4 \mathrm{~b})$. Yield $=81 \%$; white solid; m.p. $115{ }^{\circ} \mathrm{C}$. $\mathbf{R}_{\mathrm{f}}$ $\left(\mathrm{CH}_{2} \mathrm{Cl}_{2} / \mathrm{MeOH} 9: 1\right)=0.45 .[\alpha]_{\mathrm{D}}=-44.7\left(c 1.05, \mathrm{CHCl}_{3}\right) .{ }^{1} \mathrm{H}$ NMR $\left(\mathrm{CDCl}_{3}, 300 \mathrm{MHz}\right) \delta 0.88(\mathrm{t}, J=6.7 \mathrm{~Hz}, 3 \mathrm{H}), 1.27-1.60(\mathrm{~m}, 14 \mathrm{H})$, $1.72-1.82(\mathrm{~m}, 2 \mathrm{H}), 2.82(\mathrm{dd}, J=9.7 \mathrm{~Hz}$ and $J=17.8 \mathrm{~Hz}, 1 \mathrm{H}), 2.95(\mathrm{dd}, J=8.3 \mathrm{~Hz}$ and $J=17.8 \mathrm{~Hz}, 1 \mathrm{H}), 3.06-3.15(\mathrm{~m}, 1 \mathrm{H}), 4.59-4.65$ $(\mathrm{m}, 1 \mathrm{H}) \mathrm{ppm} .{ }^{13} \mathrm{C} \mathrm{NMR}\left(\mathrm{CDCl}_{3}, 75 \mathrm{MHz}\right) \delta 14.1,22.6,25.1,29.1,29.2,29.3,29.4,31.8,31.9,35.3,45.3,81.8,174.4,175.5 \mathrm{ppm}$. HRMS (ESI, m/z) : Calcd. for $\mathrm{C}_{14} \mathrm{H}_{23} \mathrm{O}_{4}: 255.1596$, found [M-H] $]^{-}: 255.1602$.

5.1.4.3. (2R,3S)-2-nonyl-5-oxo-tetrahydrofuran-3-carboxylic acid (4S,5R-4b). Yield $=78 \%$; white solid; m.p. $115{ }^{\circ} \mathrm{C}$. $\mathrm{R}_{\mathrm{f}}$

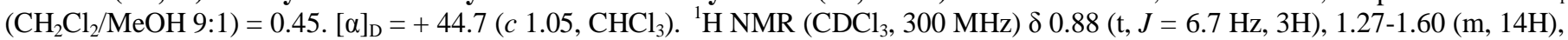
$1.72-1.82(\mathrm{~m}, 2 \mathrm{H}), 2.82(\mathrm{dd}, J=9.7 \mathrm{~Hz}$ and $J=17.8 \mathrm{~Hz}, 1 \mathrm{H}), 2.95(\mathrm{dd}, J=8.3 \mathrm{~Hz}$ and $J=17.8 \mathrm{~Hz}, 1 \mathrm{H}), 3.06-3.15(\mathrm{~m}, 1 \mathrm{H}), 4.59-4.65$ (m, 1H) ppm. ${ }^{13} \mathrm{C} \mathrm{NMR}\left(\mathrm{CDCl}_{3}, 75 \mathrm{MHz}\right) \delta 14.1,22.6,25.1,29.1,29.2,29.3,29.4,31.8,31.9,35.3,45.3,81.8,174.4,175.5 \mathrm{ppm}$. HRMS (ESI, m/z) : Calcd. for $\mathrm{C}_{14} \mathrm{H}_{23} \mathrm{O}_{4}: 255.1596$, found [M-H] $]^{-}: 255.1604$.

5.1.4.4. (2S,3R)-5-oxo-2-tridecyl-tetrahydrofuran-3-carboxylic acid (4R,5S-4c). Yield = 71\%; white solid; m.p. $114{ }^{\circ} \mathrm{C}$; ref. ${ }^{17}: 112$ ${ }^{\circ} \mathrm{C} .[\alpha]_{\mathrm{D}}=-25.3\left(c 1.01, \mathrm{CHCl}_{3}\right)$; ref. ${ }^{17}:[\alpha]_{\mathrm{D}}=-42.8\left(c\right.$ 1.76, $\left.\mathrm{CHCl}_{3}\right)$. HRMS (ESI, m/z) : Calcd. for $\mathrm{C}_{18} \mathrm{H}_{31} \mathrm{O}_{4}: 311.2222$, found $[\mathrm{M}-$ $\mathrm{H}]^{-}: 311.2225$.

5.1.4.5. (2R,3S)-5-oxo-2-tridecyl-tetrahydrofuran-3-carboxylic acid (4S,5R-4c). Yield = 66\%; white solid; m.p. $114{ }^{\circ} \mathrm{C}$; ref. ${ }^{17}: 110$ ${ }^{\circ} \mathrm{C} .[\alpha]_{\mathrm{D}}=+34.4\left(c 0.81, \mathrm{CHCl}_{3}\right)$. HRMS (ESI, m/z) : Calcd. for $\mathrm{C}_{18} \mathrm{H}_{31} \mathrm{O}_{4}: 311.2222$, found $[\mathrm{M}-\mathrm{H}]^{-}: 311.2228$. 
5.1.4.6. (2S,3R)-5-oxo-2-pentadecyl-tetrahydrofuran-3-carboxylic acid (4R,5S-4d). Yield $=92 \%$; white solid; m.p. $108{ }^{\circ} \mathrm{C}$. $\mathrm{R}_{\mathrm{f}}\left(\mathrm{CH}_{2} \mathrm{Cl}_{2} / \mathrm{MeOH} 9: 1\right)=0.33 .[\alpha]_{\mathrm{D}}=-29.9\left(c 1.12, \mathrm{CHCl}_{3}\right) .{ }^{1} \mathrm{H} \mathrm{NMR}\left(\mathrm{CDCl}_{3}, 300 \mathrm{MHz}\right) \delta 0.88(\mathrm{t}, J=6.7 \mathrm{~Hz}, 3 \mathrm{H}), 1.26-1.82(\mathrm{~m}$, $26 \mathrm{H}), 1.72-1.82(\mathrm{~m}, 2 \mathrm{H}), 2.77-2.99(\mathrm{~m}, 2 \mathrm{H}), 3.06-3.14(\mathrm{~m}, 1 \mathrm{H}), 4.59-4.65(\mathrm{~m}, 1 \mathrm{H}) \mathrm{ppm} .{ }^{13} \mathrm{C} \mathrm{NMR}\left(\mathrm{CDCl}_{3}, 75 \mathrm{MHz}\right) \delta 14.3,22.8,25.3$, 29.3, 29.5, 29.6, 29.8, 32.0, 32.1, 35.5, 45.4, 81.9, 174.4, 176.0 ppm. HRMS (ESI, m/z) : Calcd. for $\mathrm{C}_{20} \mathrm{H}_{35} \mathrm{O}_{4}:$ : 339.2541, found [M-H] : 339.2543 .

5.1.4.7. (2S,3R)-5-oxo-2-hexadecyl-tetrahydrofuran-3-carboxylic acid (4S,5R-4e).

Yield $=95 \%$; brownish solid; m.p. 114 ${ }^{\circ} \mathrm{C} . \mathrm{R}_{\mathrm{f}}\left(\mathrm{CH}_{2} \mathrm{Cl}_{2} / \mathrm{MeOH} 9: 1\right)=0.35 .[\alpha]_{\mathrm{D}}=-29.0\left(c 0.98, \mathrm{CHCl}_{3}\right) .{ }^{1} \mathrm{H} \mathrm{NMR}\left(\mathrm{CDCl}_{3}, 300 \mathrm{MHz}\right) \delta 0.88(\mathrm{t}, J=6.6 \mathrm{~Hz}, 3 \mathrm{H}), 1.27-1.56(\mathrm{~m}$, $28 \mathrm{H}), 1.72-1.81(\mathrm{~m}, 2 \mathrm{H}), 2.79(\mathrm{dd}, J=9.8 \mathrm{~Hz}$ and $J=17.8 \mathrm{~Hz}, 1 \mathrm{H}), 2.90(\mathrm{dd}, J=8.3 \mathrm{~Hz}$ and $J=17.8 \mathrm{~Hz}, 1 \mathrm{H}), 3.04-3.12(\mathrm{~m}, 1 \mathrm{H})$, 4.58-4.64 (m, 1H) ppm. ${ }^{13} \mathrm{C} \mathrm{NMR}\left(\mathrm{CDCl}_{3}, 75 \mathrm{MHz}\right) \delta 14.1,22.8,25.3,29.4,29.5,29.6,29.7,29.8,32.1,35.6,35.7,45.5,52.7,82.0$, 174.3, 175.4 ; HRMS (ESI, m/z) : Calcd. for $\mathrm{C}_{21} \mathrm{H}_{37} \mathrm{O}_{4}: 353.2697$, found [M-H] ${ }^{-}: 353.2701$.

\subsubsection{General procedure for compounds 5a-e}

A mixture of carboxy lactone $4(7.88 \mathrm{mmol})$ in a solution of methoxymagnesium monomethylcarbonate $\mathrm{MMC}$ (150 $\mathrm{mL}, 299.6 \mathrm{mmol}$ of $2 \mathrm{M}$ in DMF, 38 eq.) was heated at $135-140{ }^{\circ} \mathrm{C}$ for $70 \mathrm{~h}$ under argon atmosphere. After the system had cooled to rt, the reaction was quenched by adding a solution of $\mathrm{HCl} 10 \%(150 \mathrm{~mL})$, this solution was then extracted with $\mathrm{CH}_{2} \mathrm{Cl}_{2}(3 \mathrm{x} 100 \mathrm{~mL})$. The combined organic layers were dried with $\mathrm{MgSO}_{4}$ and concentrated under vacuum. The resulting brown oil was dissolved in a solvent mixture of acetic acid $(38 \mathrm{~mL})$, formaldehyde $(28 \mathrm{~mL}), N$-methylaniline $(9.8 \mathrm{~mL})$ and NaOAc $(1,13 \mathrm{~g})$. After stirring for $2 \mathrm{~h}$ at $\mathrm{rt}$, the mixture was poured into a solution of $\mathrm{HCl} 10 \%$. The solution was extracted with tert-butyl methyl ether ( $3 \times 100 \mathrm{~mL})$, the combined organic layers were washed once with brine and then three times with $\mathrm{H}_{2} \mathrm{O}$. The organic layer was dried with $\mathrm{MgSO}_{4}$ and concentrated under vacuum. The residue was purified over silicagel Geduran®Si 60 (diethyl ether/petroleum ether/acetic acid 3:7:0.2) to yield compounds 5.

5.1.5.1. (2S,3R)-2-heptyl-4-methylene-5-oxo-tetrahydrofuran-3-carboxylic acid (4R,5S-5a). Yield = 30\%; white solid; m.p. $71{ }^{\circ} \mathrm{C} . \mathrm{R}_{\mathrm{f}}$ (petroleum ether/diethyl ether/acetic acid 8:2:0.2) $=0.13 .[\alpha]_{\mathrm{D}}=-11.4\left(c 1.10, \mathrm{CHCl}_{3}\right) .{ }^{1} \mathrm{H} \mathrm{NMR}\left(\mathrm{CDCl}_{3}, 300 \mathrm{MHz}\right) \delta 0.88(\mathrm{t}$, $J=6.4 \mathrm{~Hz}, 3 \mathrm{H}), 1.28-1.79(\mathrm{~m}, 12 \mathrm{H}), 3.62-3.66(\mathrm{~m}, 1 \mathrm{H}), 4.82(\mathrm{~d}, J=5.3 \mathrm{~Hz}, 1 \mathrm{H}), 6.03(\mathrm{~d}, J=2.4 \mathrm{~Hz}, 1 \mathrm{H}), 6.46(\mathrm{~d}, J=2.7 \mathrm{~Hz}, 1 \mathrm{H})$ ppm. ${ }^{13} \mathrm{C} \mathrm{NMR}\left(\mathrm{CDCl}_{3}, 75 \mathrm{MHz}\right) \delta 14.2,22.7,24.8,29.1,29.2,31.8,35.8,49.6,79.1,126.2,132.5,168.6$, 174.7 ppm. HRMS (ESI, $\mathrm{m} / \mathrm{z})$ : Calcd. for $\mathrm{C}_{13} \mathrm{H}_{19} \mathrm{O}_{4}: 239.12888$, found [M-H] : 239.1292.

5.1.5.2. (2R,3S)-4-methylene-2-nonyl-5-oxo-tetrahydrofuran-3-carboxylic acid (4S,5R-5b).

Yield $=41 \%$; white solid; m.p. $93{ }^{\circ} \mathrm{C} .{ }^{25} \mathrm{R}_{\mathrm{f}}$ (petroleum ether/diethyl ether/acetic acid 8:2:0.2) $=0.20 .[\alpha]_{\mathrm{D}}=+12.82\left(c 0.975, \mathrm{CHCl}_{3}\right) .{ }^{1} \mathrm{H} \mathrm{NMR}\left(\mathrm{CDCl} \mathrm{N}_{3}, 300 \mathrm{MHz}\right) \delta$ $0.87(\mathrm{t}, J=6.6 \mathrm{~Hz}, 3 \mathrm{H}), 1.26-1.50(\mathrm{~m}, 14 \mathrm{H}), 1.71-1.76(\mathrm{~m}, 2 \mathrm{H}), 3.61-3.63(\mathrm{~m}, 1 \mathrm{H}), 4.81(\mathrm{dt}, J=5.8 \mathrm{~Hz}$ and $J=7 \mathrm{~Hz}, 1 \mathrm{H}), 6.02(\mathrm{~d}, J=$ $2.6 \mathrm{~Hz}, 1 \mathrm{H}), 6.46(\mathrm{~d}, J=3.0 \mathrm{~Hz}, 1 \mathrm{H}), 10.58(\mathrm{~s}, 1 \mathrm{H}) \mathrm{ppm} .{ }^{13} \mathrm{C} \mathrm{NMR}\left(\mathrm{CDCl}_{3}, 75 \mathrm{MHz}\right) \delta 14.0,22.6,24.7,29.1,29.2,29.4,31.8,35.7$, 49.5, 79.0, 126.2, 132.5, 168.4, 174.9 ppm. HRMS (ESI, m/z) : Calcd. for $\mathrm{C}_{15} \mathrm{H}_{23} \mathrm{O}_{4}: 267.1596$, found [M-H] $]^{-} 267.1603$.

5.1.5.3. (2S,3R)-4-methylene-2-nonyl-5-oxo-tetrahydrofuran-3-carboxylic acid (4R,5S-5b). Yield = 54\%; white solid; m.p. $93{ }^{\circ} \mathrm{C} . \mathrm{R}_{\mathrm{f}}$ (petroleum ether/diethyl ether/acetic acid 8:2:0.2) $=0.20 .[\alpha]_{\mathrm{D}}=-6.3\left(\mathrm{c} \mathrm{0.98}, \mathrm{CHCl}_{3}\right) .{ }^{1} \mathrm{H} \mathrm{NMR}\left(\mathrm{CDCl}_{3}, 300 \mathrm{MHz}\right) \delta 0.87(\mathrm{t}, J$ $=6.6 \mathrm{~Hz}, 3 \mathrm{H}), 1.26-1.50(\mathrm{~m}, 14 \mathrm{H}), 1.71-1.76(\mathrm{~m}, 2 \mathrm{H}), 3.61-3.63(\mathrm{~m}, 1 \mathrm{H}), 4.81(\mathrm{dt}, J=5.8 \mathrm{~Hz}$ and $J=7 \mathrm{~Hz}, 1 \mathrm{H}), 6.02(\mathrm{~d}, J=2.6 \mathrm{~Hz}$, $1 \mathrm{H}), 6.46(\mathrm{~d}, J=3.0 \mathrm{~Hz}, 1 \mathrm{H}), 10.58(\mathrm{~s}, 1 \mathrm{H}) \mathrm{ppm} .{ }^{13} \mathrm{C} \mathrm{NMR}\left(\mathrm{CDCl}_{3}, 75 \mathrm{MHz}\right) \delta 14.0,22.6,24.7,29.1,29.2,29.4,31.8,35.7,49.5,79.0$, 126.2, 132.5, 168.4, 174.9 ppm. HRMS (ESI, m/z) : Calcd. for $\mathrm{C}_{15} \mathrm{H}_{23} \mathrm{O}_{4}: 267.1596$, found [M-H] : 267.1603.

5.1.5.4. (2R,3S)-4-methylene-5-oxo-2-tridecyl-tetrahydrofuran-3-carboxylic acid (4S,5R-5c). This compound was prepared as published. ${ }^{17}$ Yield $=36 \%$. m.p. $108{ }^{\circ} \mathrm{C}$, ref. ${ }^{17}: 104-105{ }^{\circ} \mathrm{C} .[\alpha]_{\mathrm{D}}=+18.3\left(c 0.24, \mathrm{CH}_{2} \mathrm{Cl}_{2}\right)$, ref. ${ }^{17}:[\alpha]_{\mathrm{D}}=+13.6\left(c 1.72, \mathrm{CHCl}_{3}\right) . \mathrm{HRMS}$ $(\mathrm{ESI}, \mathrm{m} / \mathrm{z})$ : Calcd. for $\mathrm{C}_{19} \mathrm{H}_{31} \mathrm{O}_{4}: 323.22223$, found $[\mathrm{M}-\mathrm{H}]^{-}: 324.2228$.

5.1.5.5. (2S,3R)-4-methylene-5-oxo-2-tridecyl-tetrahydrofuran-3-carboxylic acid (4R,5S-5c). This compound was prepared as published. ${ }^{17}$ Yield $=28 \%$. m.p. $108{ }^{\circ} \mathrm{C}$, ref. ${ }^{17}: 104-105{ }^{\circ} \mathrm{C} .[\alpha]_{\mathrm{D}}=-7.9\left(c 0.99, \mathrm{CHCl}_{3}\right)$, ref. $\left.{ }^{17}:[\alpha]_{\mathrm{D}}=-13.2\left(c 1.52, \mathrm{CHCl}_{3}\right).\right) . \mathrm{HRMS}$ $(\mathrm{ESI}, \mathrm{m} / \mathrm{z})$ : Calcd. for $\mathrm{C}_{19} \mathrm{H}_{32} \mathrm{O}_{4}: 324.2301$, found $[\mathrm{M}]^{+}: 324.2291$.

5.1.5.6. (2S,3R)-4-methylene-5-oxo-2-pentadecyl-tetrahydrofuran-3-carboxylic acid (4R,5S-5d). Yield = 56\%; white solid; m.p. $108{ }^{\circ} \mathrm{C} . \mathrm{R}_{\mathrm{f}}$ (petroleum ether/diethyl ether/acetic acid 6:3.8:0.2) $=0.33 .[\alpha]_{\mathrm{D}}=-9.4\left(c 1.13, \mathrm{CHCl}_{3}\right) .{ }^{1} \mathrm{H} \mathrm{NMR}\left(\mathrm{CDCl}{ }_{3}, 300 \mathrm{MHz}\right) \delta 0.88$ $(\mathrm{t}, J=6.5 \mathrm{~Hz}, 3 \mathrm{H}), 1.26-1.75(\mathrm{~m}, 28 \mathrm{H}), 3.62-3.64(\mathrm{~m}, 1 \mathrm{H}), 4.81(\mathrm{dt}, J=6.0 \mathrm{~Hz}$ and $J=12.3 \mathrm{~Hz}, 1 \mathrm{H}), 6.02(\mathrm{~d}, J=2.4 \mathrm{~Hz}, 1 \mathrm{H}), 6.47(\mathrm{~d}$, $J=2.8 \mathrm{~Hz}, 1 \mathrm{H}) \mathrm{ppm} .{ }^{13} \mathrm{C} \mathrm{NMR}\left(\mathrm{CDCl}_{3}, 75 \mathrm{MHz}\right) \delta 14.3,22.8,24.9,29.3,29.5,29.6,29.8,32.1,35.9,49.6,79.0,126.2,132.5,168.4$, 174.8 ppm. HRMS (ESI, m/z) : Calcd. for $\mathrm{C}_{21} \mathrm{H}_{35} \mathrm{O}_{4} \mathrm{Na}: 375.2111$, found $[\mathrm{M}+\mathrm{Na}]^{+}: 375.2518$.

5.1.5.7. (2S,3R)-2-hexadecyl-4-methylene-5-oxo-tetrahydrofuran-3-carboxylic acid (4R,5S-5e). Yield = 45\%; white solid; m.p. $107{ }^{\circ} \mathrm{C} . \mathrm{R}_{\mathrm{f}}$ (petroleum ether/diethyl ether/acetic acid 6:3.8:0.2) $=0.33 .[\alpha]_{\mathrm{D}}=-2.3\left(c 1.01, \mathrm{CHCl}_{3}\right) .{ }^{1} \mathrm{H} \mathrm{NMR}\left(\mathrm{CDCl}_{3}, 300 \mathrm{MHz}\right) \delta 0.88$ $(\mathrm{t}, J=6.7 \mathrm{~Hz}, 3 \mathrm{H}), 1.26-1.55(\mathrm{~m}, 28 \mathrm{H}), 1.68-1.81(\mathrm{~m}, 2 \mathrm{H}), 3.63(\mathrm{ddd}, J=5.6 \mathrm{~Hz}, J=2.5 \mathrm{~Hz}$ and $J=2.8 \mathrm{~Hz}, 1 \mathrm{H}), 4.81(\mathrm{dt}, J=5.8 \mathrm{~Hz}$ and $J=7 \mathrm{~Hz}, 1 \mathrm{H}), 6.03(\mathrm{~d}, J=2.7 \mathrm{~Hz}, 1 \mathrm{H}), 6.47(\mathrm{~d}, J=3.0 \mathrm{~Hz}, 1 \mathrm{H}) \mathrm{ppm} .{ }^{13} \mathrm{C} \mathrm{NMR}\left(\mathrm{CDCl}_{3}, 75 \mathrm{MHz}\right) \delta 14.3,22.8,24.9,29.3,29.5$, 29.6, 29.7, 29.8, 32.1, 35.9, 49.6, 79.0, 126.0, 132.6, 168.3, $174.2 \mathrm{ppm}$. HRMS (ESI, m/z) : Calcd. for $\mathrm{C}_{22} \mathrm{H}_{37} \mathrm{O}_{4}: 365.2697$, found [M$\mathrm{H}]: 365.2695$

\subsubsection{General procedure for compounds 6a-e}

To a solution of compound $5(1.99 \mathrm{mmol})$ in anhydrous DMF $(17 \mathrm{~mL})$ under argon atmosphere, was added $\mathrm{NEt}_{3}(279 \mu \mathrm{L}, 1.99$ mmol, 1 eq.). After stirring overnight at $\mathrm{rt}$, the reaction was quenched by adding a solution of $\mathrm{HCl} 1 \mathrm{M}$, this solution was then extracted with diethyl ether $(3 \times 50 \mathrm{~mL})$. The combined organic layers were washed with $\mathrm{H}_{2} \mathrm{O}$, dried with $\mathrm{MgSO}_{4}$ and concentrated under 
vacuum. The residue was purified over silicagel Geduran ${ }$ Si 60 (diethyl ether/petroleum ether/acetic acid 3:7:0.2) to yield the desired compound 6.

5.1.6.1. (S)-2-heptyl-4-methyl-5-oxo-2,5-dihydrofuran-3-carboxylic acid (5S-6a) (B-7). Yield = 71\%; white solid; m.p. $120{ }^{\circ} \mathrm{C}$. $\mathrm{R}_{\mathrm{f}}$ (petroleum ether/diethyl ether/acetic acid 8:2:0.2) $=0.21 .[\alpha]_{\mathrm{D}}=-11.4\left(c 1.10, \mathrm{CHCl}_{3}\right),{ }^{1} \mathrm{H} \mathrm{NMR}(\mathrm{CDCl} 3,300 \mathrm{MHz}) \delta 0.88(\mathrm{t}, J=$ $6.7 \mathrm{~Hz}, 3 \mathrm{H}), 1.27-1.67(\mathrm{~m}, 12 \mathrm{H}), 2.08-2.19(\mathrm{~m}, 1 \mathrm{H}), 2.25(\mathrm{~d}, J=2.1 \mathrm{~Hz}, 3 \mathrm{H}), 5.11-5.15(\mathrm{~m}, 1 \mathrm{H}) \mathrm{ppm} .{ }^{13} \mathrm{C} \mathrm{NMR}\left(\mathrm{CDCl}_{3}, 75 \mathrm{MHz}\right) \delta$ 11.2, 14.2, 22.7, 24.9, 29.2, 29.3, 31.8, 32.9, 81.5, 140.3, 146.7, 166.7, 172.7 ppm. HRMS (ESI, m/z) : Calcd. for $\mathrm{C}_{13} \mathrm{H}_{19} \mathrm{O}_{4}: 239.1289$, found $[\mathrm{M}-\mathrm{H}]^{-}:$239.1291. Anal. Calcd. For $\mathrm{C}_{13} \mathrm{H}_{20} \mathrm{O}_{4}$ : C, $64.98 ; \mathrm{H}, 8.39$. Found : C, 64.17 ; H, 8.25. HPLC : Chiralpak IC, $n$ heptane/MtBE/TFA 80:20:0.1, $250 \mathrm{~nm}, 1 \mathrm{~mL} / \mathrm{min}, 0.5 \mathrm{mg} / \mathrm{mL} . \mathrm{T}_{\mathrm{R}}=15.09 \mathrm{~min}$, ee $=91 \%$.

5.1.6.2. (S)-4-methyl-2-nonyl-5-oxo-2,5-dihydrofuran-3-carboxylic acid (5S-6b) (B-8). $\quad$ Yield = 65\%; white solid; m.p. $120{ }^{\circ} \mathrm{C}$. $\mathrm{R}_{\mathrm{f}}$ (petroleum ether/diethyl ether/acetic acid 8:2:0.2) $=0.29 .[\alpha]_{\mathrm{D}}=-36.3\left(c 1.30, \mathrm{CHCl}_{3}\right) .{ }^{1} \mathrm{H} \mathrm{NMR}\left(\mathrm{CDCl}{ }_{3}, 300 \mathrm{MHz}\right) \delta 0.88(\mathrm{t}, J=$ $6.7 \mathrm{~Hz}, 3 \mathrm{H}), 1.26-1.67(\mathrm{~m}, 16 \mathrm{H}), 2.09-2.16(\mathrm{~m}, 1 \mathrm{H}), 2.24(\mathrm{~d}, J=2.1 \mathrm{~Hz}, 3 \mathrm{H}), 5.12-5.13(\mathrm{~m}, 1 \mathrm{H}) \mathrm{ppm} .{ }^{13} \mathrm{C} \mathrm{NMR}\left(\mathrm{CDCl}_{3}, 75 \mathrm{MHz}\right) \delta$ 11.0, 14.1, 22.6, 24.7, 29.1, 29.2, 29.3, 29.4, 31.8, 32.7, 81.4, 139.7, 146.7, 165.5, $172.6 \mathrm{ppm}$. HRMS (ESI, m/z) : Calcd. for $\mathrm{C}_{15} \mathrm{H}_{24} \mathrm{O}_{4} \mathrm{Na}: 291.15723$, found $[\mathrm{M}+\mathrm{Na}]^{+}:$291.1572. Anal. Calcd. For $\mathrm{C}_{15} \mathrm{H}_{24} \mathrm{O}_{4}: \mathrm{C}, 67.14 ; \mathrm{H}, 9.01$. Found : C, 67.97 ; H, 9.07. HPLC : Chiralpak IC, $n$-heptane/MtBE/TFA 80:20:0.1, $250 \mathrm{~nm}, 1 \mathrm{~mL} / \mathrm{min}, 0.5 \mathrm{mg} / \mathrm{mL}$. $\mathrm{T}_{\mathrm{R}}=16.92 \mathrm{~min}$, ee $=97 \%$.

5.1.6.3. (R)-4-methyl-2-nonyl-5-oxo-2,5-dihydrofuran-3-carboxylic acid (5R-6b) (B-9). ${ }^{26}$

Yield $=67 \%$; white solid; m.p. $11{ }^{\circ} \mathrm{C} . \mathrm{R}_{\mathrm{f}}$ (petroleum ether/diethyl ether/acetic acid 8:2:0.2) $=0.29 .[\alpha]_{\mathrm{D}}=+37.3\left(c 1.04, \mathrm{CHCl}_{3}\right) .{ }^{1} \mathrm{H} \mathrm{NMR}\left(\mathrm{CDCl}{ }_{3}, 300 \mathrm{MHz}\right) \delta 0.88$ $(\mathrm{t}, J=6.7 \mathrm{~Hz}, 3 \mathrm{H}), 1.26-1.67(\mathrm{~m}, 16 \mathrm{H}), 2.09-2.16(\mathrm{~m}, 1 \mathrm{H}), 2.24(\mathrm{~d}, J=2.1 \mathrm{~Hz}, 3 \mathrm{H}), 5.12-5.13(\mathrm{~m}, 1 \mathrm{H}) \mathrm{ppm} .{ }^{13} \mathrm{C} \mathrm{NMR}\left(\mathrm{CDCl} \mathrm{N}_{3}, 75\right.$ MHz) $\delta 11.0,14.1,22.6,24.7,29.1,29.2,29.3,29.4,31.8,32.7,81.4,139.7,146.7,165.5,172.6$ ppm. HRMS (ESI, m/z) : Calcd. for $\mathrm{C}_{15} \mathrm{H}_{23} \mathrm{O}_{4}: 267.15963$, found [M-H] : 267.1602. Anal. Calcd. For $\mathrm{C}_{15} \mathrm{H}_{24} \mathrm{O}_{4}: \mathrm{C}, 67.14 ; \mathrm{H}, 9.01$. Found : C, 66.90; H, 8.98. HPLC : Chiralpak IC, $n$-heptane/MtBE/TFA 80:20:0.1, $250 \mathrm{~nm}, 1 \mathrm{~mL} / \mathrm{min}, 0.5 \mathrm{mg} / \mathrm{mL}$. $\mathrm{T}_{\mathrm{R}}=18.92 \mathrm{~min}$, ee $=99 \%$.

5.1.6.4. (-)-Lichesterinic acid (5S-6c) (B-10).

Yield $=69 \%$; white solid; m.p. $122{ }^{\circ} \mathrm{C}$; ref. ${ }^{27}: 120-121{ }^{\circ} \mathrm{C} .[\alpha]_{\mathrm{D}}=-23.5(c$ 1.055, $\left.\mathrm{CHCl}_{3}\right)$; ref. ${ }^{27}[\alpha]_{\mathrm{D}}=-35\left(c 0.6, \mathrm{CHCl}_{3}\right)$. HRMS (ESI, m/z) : Calcd. for $\mathrm{C}_{19} \mathrm{H}_{32} \mathrm{O}_{4}: 324.2301$, found [M] $]^{+}: 324.2288$. Anal. Calcd. For $\mathrm{C}_{19} \mathrm{H}_{32} \mathrm{O}_{4}$ : C, $70.33 ; \mathrm{H}, 9.94$. Found : C, $71.48 ; \mathrm{H}, 10.03$. HPLC : Chiralpak IA, 100\% ACN + 0.1\% HCOOH, $210 \mathrm{~nm}, 1$ $\mathrm{mL} / \mathrm{min}, 0.5 \mathrm{mg} / \mathrm{mL}$. $\mathrm{T}_{\mathrm{R}}=6.16 \mathrm{~min}$, ee $=98 \%$.

5.1.6.5. (+)-Lichesterinic acid (5R-6c) (B-11). Yield $=71 \%$; white solid; m.p. $122{ }^{\circ} \mathrm{C}$; ref. ${ }^{28}: 120-122{ }^{\circ} \mathrm{C} .[\alpha]_{\mathrm{D}}+24.9(c 1.03$, $\mathrm{CHCl}_{3}$ ); ref. ${ }^{28}:[\alpha]_{\mathrm{D}}=+31.9$. HRMS (ESI, m/z) : Calcd. for $\mathrm{C}_{19} \mathrm{H}_{32} \mathrm{O}_{4}: 324.2301$, found $[\mathrm{M}]^{+}: 324.2288$. Anal. Calcd. For $\mathrm{C}_{19} \mathrm{H}_{32} \mathrm{O}_{4}$ : C, 70.33 ; H, 9.94. Found : C, 71.20 ; H, 9.95. HPLC : Chiralpak IA, 100\% ACN + 0.1\% HCOOH, $210 \mathrm{~mm}, 1 \mathrm{~mL} / \mathrm{min}, 0.5 \mathrm{mg} / \mathrm{mL} . \mathrm{T}$ R $=6.91 \mathrm{~min}, \mathrm{ee}=91 \%$.

5.1.6.6. (S)-4-methyl-5-oxo-2-pentadecyl-2,5-dihydrofuran-3-carboxylic acid (5S-6d) (B-12). Yield = 89\%; white solid; m.p. $120{ }^{\circ} \mathrm{C} . \mathrm{R}_{\mathrm{f}}$ (petroleum ether/diethyl ether/acetic acid 6:3.8:0.2) $=0.38 .[\alpha]_{\mathrm{D}}=-21.8\left(c 0.98, \mathrm{CHCl}_{3}\right) .{ }^{1} \mathrm{H} \mathrm{NMR}\left(\mathrm{CDCl}_{3}, 300 \mathrm{MHz}\right) \delta 0.88$ $(\mathrm{t}, J=6.5 \mathrm{~Hz}, 3 \mathrm{H}), 1.25-1.64(\mathrm{~m}, 28 \mathrm{H}), 2.09-2.20(\mathrm{~m}, 1 \mathrm{H}), 2.25(\mathrm{~d}, J=1.8 \mathrm{~Hz}, 3 \mathrm{H}), 5.12-5.14(\mathrm{~m}, 1 \mathrm{H}) \mathrm{ppm} .{ }^{13} \mathrm{C} \mathrm{NMR}(\mathrm{CDCl}, 75$ MHz) $\delta 11.2,14.3,22.8,24.9,29.4,29.5,29.7,29.8,32.1,32.9,81.5,140.3,146.8,167.0,172.8$ ppm. HRMS (ESI, m/z) : Calcd. for $\mathrm{C}_{21} \mathrm{H}_{35} \mathrm{O}_{4}: 351.25408$, found [M-H] $]^{-}: 351.2545$. Anal. Calcd. For $\mathrm{C}_{21} \mathrm{H}_{36} \mathrm{O}_{4}: \mathrm{C}, 71.55 ; \mathrm{H}, 10.29$. Found : C, 71.80; H, 10.37. HPLC : Chiralpak IA, $100 \% \mathrm{ACN}+0.1 \% \mathrm{HCOOH}, 210 \mathrm{~nm}, 1 \mathrm{~mL} / \mathrm{min}, 0.5 \mathrm{mg} / \mathrm{mL}$. $\mathrm{T}_{\mathrm{R}}=7.58 \mathrm{~min}$, ee $=86 \%$.

5.1.6.7. (S)-2-hexadecyl-4-methyl-5-oxo-2,5-dihydrofuran-3-carboxylic acid (5S-6e) (B-13). Yield = 62\%; white solid; m.p. $125{ }^{\circ} \mathrm{C} . \mathrm{R}_{\mathrm{f}}$ (petroleum ether/diethyl ether/acetic acid 6:3.8:0.2) $=0.38 .[\alpha]_{\mathrm{D}}=-25.9\left(c 1.015, \mathrm{CHCl}_{3}\right) .{ }^{1} \mathrm{H} \mathrm{NMR}\left(\mathrm{CDCl}_{3}, 300 \mathrm{MHz}\right) \delta$ $0.88(\mathrm{t}, J=6.7 \mathrm{~Hz}, 3 \mathrm{H}), 1.26-1.67(\mathrm{~m}, 30 \mathrm{H}), 2.07-2.18(\mathrm{~m}, 1 \mathrm{H}), 2.24(\mathrm{~d}, J=2.1 \mathrm{~Hz}, 3 \mathrm{H}), 5.09-5.13(\mathrm{~m}, 1 \mathrm{H}) \mathrm{ppm} .{ }^{13} \mathrm{C} \mathrm{NMR}(\mathrm{CDCl}, 75$ MHz) $\delta 11.2,14.3,22.8,24.9,29.4,29.5,29.7,29.8,32.1,32.9,81.5,140.3,146.8,166.7,172.8$ ppm. HRMS (ESI, m/z) : Calcd. for $\mathrm{C}_{22} \mathrm{H}_{37} \mathrm{O}_{4}: 365.26974$, found [M-H] : 365.2699. Anal. Calcd. For $\mathrm{C}_{22} \mathrm{H}_{38} \mathrm{O}_{4}: \mathrm{C}, 72.09 ; \mathrm{H}, 10.45$. Found : C, $72.24 ; \mathrm{H}, 10.39$. HPLC : Chiralpak IA, $100 \% \mathrm{ACN}+0.1 \% \mathrm{HCOOH}, 210 \mathrm{~nm}, 1 \mathrm{~mL} / \mathrm{min}, 0.5 \mathrm{mg} / \mathrm{mL}$. $\mathrm{T}_{\mathrm{R}}=8.09 \mathrm{~min}$, ee $>99 \%$.

\subsubsection{Chemical compounds}

All butyrolactones were dissolved in pure DMSO and then diluted with pure methanol to get $3 \mu \mathrm{g} / \mathrm{mL}$ and to reach a final concentration of DMSO less than $25 \%$. After that, they were filter sterilized through a $0.22-\mu \mathrm{m}$-pore-size filter.

\subsection{Biological activity}

\subsubsection{Bacterial culture}

Streptococcus gordonii DL1 was used in this study ${ }^{29}$. Brain-heart infusion broth (BHI) (DIFCO, France) and/or blood Columbia agar plates (AES Chemunex, France) supplemented with hemin $(5 \mu \mathrm{g} / \mathrm{mL})$ and menadione $(1 \mu \mathrm{g} / \mathrm{mL})$ (Sigma Aldrich, France) were used for its growth. S. gordonii was grown under anaerobic conditions $\left(\mathrm{N}_{2}-\mathrm{H}_{2}-\mathrm{CO}_{2}\right.$ [80:10:10]) at $37{ }^{\circ} \mathrm{C}$ to mimic the conditions created by the microorganisms colonizing the tooth surface rendering it rapidly anaerobic. ${ }^{30}$

\subsubsection{Cell lines}

Two different human cell lines were chosen: a gingival epithelial carcinoma cell line, Ca9-22 (Health Science Research Resources Bank, Osaka, Japan) and a macrophage-like monocytic leukemia cell line, THP-1. Ca9-22 cells were grown in Dulbecco's Modified Eagle Medium (DMEM) (Lonza, France) whereas RPMI 1640 medium with sodium pyruvate $(1 \mathrm{mM})$ and Hepes buffer (1M) (Sigma Aldrich) was used for THP-1 growth. Both lines were grown in a $5 \% \mathrm{CO}_{2}$ atmosphere at $37{ }^{\circ} \mathrm{C}$ and their media were supplemented with L-Glutamine ( $2 \mathrm{mM}), 10 \%$ heat-inactivated fetal bovine serum (FBS, Lonza, France) and antibiotics (penicillin $100 \mathrm{mg} / \mathrm{mL}$ and 
streptomycine $50 \mathrm{mg} / \mathrm{mL}$ ) (Sigma Aldrich). For THP-1 differentiation into macrophages, Phorbol 12-myristate 13-acetate (PMA) (Sigma Aldrich) was used at $10 \mathrm{ng} / \mathrm{mL}$ for 72 hours.

\subsubsection{Antibacterial Assay}

\subsubsection{Agar dilution}

Agar dilution assay was chosen to test the antibacterial activity against $S$. gordonii strain under anaerobic conditions as recommended by the Clinical and Laboratory Standards Institute (CLSI). ${ }^{31}$ Briefly, Columbia agar is mixed with hoarse blood and different concentrations of butyrolactones $(300,250,200,150,100,90,80$ and $70 \mu \mathrm{g} / \mathrm{mL})$, or doxycycline $(1: 2$ serial dilutions from 1.31 to $2 \times 10^{-5} \mu \mathrm{g} / \mathrm{mL}$ ) as a positive control or the mixture of solvents used to dissolute the compounds (DMSO + methanol) or distilled water as negative controls and left to solidify. The agar mixture is then inoculated with $2 \mu 1$ spot containing $10^{5} \mathrm{CFU} / \mathrm{mL}$ before its incubation for 24 hours under anaerobic conditions. The lowest concentration of the mixture that prevented the growth of the bacteria was then determined and the corresponding concentration was defined as the Minimal Inhibitory Concentration (MIC). This was repeated three times.

\subsubsection{Broth microdilution}

Broth microdilution test was done to confirm the results in broth as described by CLSI. ${ }^{31}$ In brief, starting with $300 \mathrm{or} 32.8 \mu \mathrm{g} / \mathrm{mL}$ as an initial concentration for the compounds to be tested or the positive control, doxycycline, respectively, 1:2 serial dilutions were made in BHI in a 96-well microtiter plate (Sterile, Flat bottom, with lid, Greiner Bio-one, Germany). Each well was then inoculated by $3 \times 10^{7} \mathrm{CFU} / \mathrm{mL}$ of $S$. gordonii. In addition, the mixture of the solvents (DMSO + methanol) used to dissolute the compounds was $1: 2$ serially diluted to check their activity. Then, the plate is incubated for 24 hours under anaerobic conditions after which the clear wells will be spreaded on Columbia Petri plates to be incubated for another 24 hours. The clear well with the lowest concentration represents the MIC which has inhibited the visible bacterial growth and the Petri plate showing no colonial growth will be the MBC defined as the lowest concentration that killed $\geq 99 \%$ of the initial inoculum.

\subsubsection{Cytotoxicity}

Each well of a 96-well plate (Sterile, Flat bottom, with lid, Greiner Bio-one, Germany) was seeded with 70000 cells after their trypsination and counting in case of Ca9-22 cells or only counting for THP-1. Ca9-22 cells were incubated for 24 hours whereas THP-1 cells were incubated with PMA for 72 hours. After that and for the two cell lines, the contents of the wells were removed and the compounds or only media as negative controls were added to be incubated for 24 hours. The compounds best inhibitory concentrations, MICs, were chosen to test whether they have a cytotoxic effect or not and Triton $1 \%$ was used as positive control. Finally, LDH and MTT assays were done to investigate the cytotoxicity. The experiments were done three times in triplicate.

\subsubsection{LDH}

According to Promega protocol, $50 \mu \mathrm{L}$ of the supernatant from each well was transferred into a new 96 -well plate. Then, $50 \mu \mathrm{L}$ of the CytoTox Reagent was added to each well and the plate was incubated for 30 minutes in the dark at room temperature. Finally, 50 $\mu \mathrm{L}$ of the stop solution was added and the O.D was then read at $490 \mathrm{~nm}$.

\subsubsection{MTT}

Ten $\mu \mathrm{L}$ of $5 \mathrm{mg} / \mathrm{mL}$ MTT, 3-(4,5-dimethylthiazol-2-yl)-2,5-diphenyl tetrazolium bromide (Sigma Aldrich, France), prepared in PBS and filter sterilized through a $0.22 \mu \mathrm{m}$ filter, was added to the wells containing $100 \mu \mathrm{L}$ of medium. The 96 -well plate was then incubated for 4 hours at $37{ }^{\circ} \mathrm{C}$ under $5 \% \mathrm{CO}_{2}$. After that, $100 \mu \mathrm{L}$ of acid-isopropanol, $0.04 \mathrm{~N} \mathrm{HCL}$ in isopropanol, was added to the wells and mixed very well to dissolve the formazan crystals. Finally, the O.D was read after a few minutes at $595 \mathrm{~nm}$ and at $655 \mathrm{~nm}$ (measurement and reference, respectively). ${ }^{32}$ The results were presented as percent MTT activity where the readings for the untreated control cells were considered as $100 \%$.

\section{Funding}

The research was supported by Rennes I University, CNRS, Association of Specialization and Scientific Orientation and Melanolichen Grant.

\section{Acknowledgments}

We acknowledge Pr J.Boustie (Head of PNSCM team) for his helpful discussion. We would also like to thank C. Le Lann and N. Oliviero (EA 1254 - Rennes I university), and Nathalie Legrave (UMR CNRS 6226 - Rennes I University) for their technical assistance.

\section{References}

1 D. I. Andersson and D. Hughes, Drug Resist. Updat., 2012, 15, 162-172.

2 A. V. Khan, Q. U. Ahmed, I. Shukla and A. A. Khan, Asian Pac. J. Trop. Biomed., 2012, 2, 189-194.

3 M. Simões, R. N. Bennett and E. A. S. Rosa, Nat. Prod. Rep., 2009, 26, 746.

4 S. Nabavi, A. Di Lorenzo, M. Izadi, E. Sobarzo-Sánchez, M. Daglia and S. Nabavi, Nutrients, 2015, 7, 7729-7748.

5 G. Shrestha, J. Raphael, S. D. Leavitt and L. L. St. Clair, Pharm. Biol., 2014, 52, 1262-1266.

6 G. Shrestha and L. L. St. Clair, Phytochem. Rev., 2013, 12, 229-244.

7 J. Boustie and M. Grube, Plant Genet. Resour. Charact. Util., 2005, 3, 273-287.

8 V. Shukla, G. P. Joshi and M. S. M. Rawat, Phytochem. Rev., 2010, 9, 303-314. 
9 M. Bačkorová, R. Jendželovský, M. Kello, M. Bačkor, J. Mikeš and P. Fedoročko, Toxicol. Vitro Int. J. Publ. Assoc. Bibra, 2012, 26, $462-468$.

10 J. cyr Yombi, L. Belkhir, S. Jonckheere, D. Wilmes, O. Cornu, B. Vandercam and H. Rodriguez-Villalobos, Bmc Infect. Dis., 2012, $12,215$.

11 N. J. Wood, H. F. Jenkinson, S. A. Davis, S. Mann, D. J. O’Sullivan and M. E. Barbour, J. Mater. Sci. Mater. Med., $2015,26,201$.

12 R. Huang, M. Li, M. Ye, K. Yang, X. Xu and R. L. Gregory, Appl. Environ. Microbiol., 2014, 80, 7212-7218.

13 M. Kuboniwa and R. J. Lamont, Periodontol. 2000, 2010, 52, 38-52.

14 C. Y. Loo, D. A. Corliss and N. Ganeshkumar, J. Bacteriol., 2000, 182, 1374-1382.

15 J. D. Rogers, E. M. Haase, A. E. Brown, C. W. Douglas, J. P. Gwynn and F. A. Scannapieco, Microbiol. Read. Engl., 1998,144 ( Pt 5), $1223-1233$.

16 C. J. Cavallito, D. M. Fruehauf and J. H. Bailey, J. Am. Chem. Soc., 1948, 70, 3724-3726.

17 S. Braukmüller and R. Brückner, Eur. J. Org. Chem., 2006, 2110-2118.

18 A. K. Perepogu, D. Raman, U. S. N. Murty and V. J. Rao, Synth. Commun., 2010, 40, 686-696.

19 J. D. Guzman, A. Gupta, D. Evangelopoulos, C. Basavannacharya, L. C. Pabon, E. A. Plazas, D. R. Munoz, W. A. Delgado, L. E. Cuca, W. Ribon, S. Gibbons and S. Bhakta, J. Antimicrob. Chemother., 2010, 65, 2101-2107.

20 Y. Yang, X. Ye, X. Li, J. Zhen, B. Zhang and L. Yuan, Planta Med., 2007, 73, 602-604.

21 F. L. S. Sebastianes, N. Cabedo, N. E. Aouad, A. M. M. P. Valente, P. T. Lacava, J. L. Azevedo, A. A. Pizzirani-Kleiner and D. Cortes, Curr. Microbiol., 2012, 65, 622-632.

22 S. Kitani, K. T. Miyamoto, S. Takamatsu, E. Herawati, H. Iguchi, K. Nishitomi, M. Uchida, T. Nagamitsu, S. Omura, H. Ikeda and T. Nihira, Proc. Natl. Acad. Sci., 2011, 108, 16410-16415.

23 T. Berkenbusch and R. Brückner, Tetrahedron, 1998, 54, 11471-11480.

24 R. A. Fernandes and A. K. Chowdhury, Eur. J. Org. Chem., 2011, 2011, 1106-1112.

25 F. P. Kuhajda, E. S. Pizer, J. N. Li, N. S. Mani, G. L. Frehywot and C. A. Townsend, Proc. Natl. Acad. Sci. U. S. A., 2000, 97, 3450-3454.

26 J. Boustie, M.-D. Galibert-Anne, F. Lohezic-Le Devehat, M. Chollet-Krugler, S. Tomasi, N. Mouchet and B. Legouin-Gardadennec, US Pat. US 20150105459, 2015.

27 S. Huneck and R. Takeda, Z. Für Naturforschung B, 1992, 47.

28 S. Huneck, K. Schreiber, G. Höfle and G. Snatzke, Journ Hattori Bot Lab, 1979, 45, 1-23.

29 O. Nicolle, A. Rouillon, H. Guyodo, Z. Tamanai-Shacoori, F. Chandad, V. Meuric and M. Bonnaure-Mallet, Fems Immunol. Med. Microbiol., 2010, no-no.

30 R. M. Donlan and J. W. Costerton, Clin. Microbiol. Rev., 2002, 15, 167-193.

31 D. W. Hecht and National Committee for Clinical Laboratory Standards, Methods for antimicrobial susceptibility testing of anaerobic bacteria: approved standard, sixth edition, NCCLS, Wayne, Pa., 2004.

32 T. Mosmann, J. Immunol. Methods, 1983, 65, 55-63. 